\title{
Exploring oxidative modifications of Tyrosine: an update on mechanisms of formation, advances in analysis and biological consequences
}

\author{
Chantal Houée-Lévin ${ }^{1}$, Krzysztof Bobrowski ${ }^{2}$, Lubica Horakova ${ }^{3}$, Betul \\ Karademir $^{4}$, Christian Schöneich ${ }^{5}$, Michael J. Davies ${ }^{6}$, Corinne M. Spickett ${ }^{7}$. \\ ${ }^{1}$ Laboratoire de Chimie Physique, UMR 8000, Université Paris Sud, Orsay, France. ${ }^{1}$ INCT, \\ Also at CNRS, Orsay, France. \\ ${ }^{2}$ Scientific Department - Centre of Radiation Research and Technology, Institute of Nuclear \\ Chemistry and Technology, Dorodna 16, 03-195, Warsaw, Poland. \\ ${ }^{3}$ Institute of Experimental Pharmacology and Toxicology, Slovak Academy of Sciences, \\ Dubravska 9, 84104 Bratislava, Slovakia. \\ ${ }^{4}$ Marmara University, School of Medicine, Department of Biochemistry, Haydarpasa, \\ Istanbul, Turkey. \\ ${ }^{5}$ Department of Pharmaceutical Chemistry, University of Kansas, Lawrence, KS 66047 , \\ USA. \\ ${ }^{6}$ Panum Institute, Department of Biomedical Sciences, University of Copenhagen, \\ Blegdamsvej 3, DK-2200 Copenhagen N, Denmark. \\ ${ }^{7}$ School of Life and Health Sciences, Aston University, Birmingham, UK.
}

Corresponding authors:

Dr Corinne M. Spickett, Email: c.m.spickett@aston.ac.uk; Tel: +44 1212044085

Dr Chantal Houée-Lévin, Email: chantal.houee@u-psud.fr 


\begin{abstract}
Protein oxidation is increasingly recognized as an important modulator of biochemical pathways controlling both physiological and pathological processes. While much attention has focused on cysteine modifications in reversible redox signaling, there is increasing evidence that other protein residues are oxidized in vivo with impact on cellular homeostasis and redox signaling pathways. A notable example is tyrosine, which can undergo a number of oxidative post-translational modifications to form 3-hydroxy-tyrosine, tyrosine crosslinks, 3-nitrotyrosine and halogenated tyrosine, with different effects on cellular functions. Tyrosine oxidation has been studied extensively in vitro, and this has generated detailed information about the molecular mechanisms that may occur in vivo. An important aspect of studying tyrosine oxidation both in vitro and in biological systems is the ability to monitor the formation of oxidized derivatives, which depends on a variety of analytical techniques. While antibody-dependent techniques such as ELISAs are commonly used, these have limitations, and more specific assays based on spectroscopic or spectrometric techniques are required to provide information on the exact residues modified and the nature of the modification. These approaches have helped understanding of the consequences of tyrosine oxidation in biological systems, especially its effects on cell signaling and cell dysfunction, linking to roles in disease. There is mounting evidence that tyrosine oxidation processes are important in vivo and can contribute to cellular pathology.
\end{abstract}

\title{
Keywords :
}

Tyrosine oxidation; Tyrosine nitration; oxidizing free radicals; redox balance; time resolved techniques, mass spectrometry, antibody-dependent techniques. 


\section{Introduction}

Biologically relevant free radicals and non-radical oxidants, often collectively known as reactive oxygen and nitrogen species (ROS, RNS), generate a variety of different responses in living organisms, from apoptosis, growth arrest and cell death to activation, differentiation and proliferation [1-3]. At high concentrations, they are hazardous and can damage all major cellular constituents. However, nitric oxide ( $\mathrm{NO}$ ), superoxide radical anion $\left(\mathrm{O}_{2}^{\bullet}\right.$ ), and hydrogen peroxide $\left(\mathrm{H}_{2} \mathrm{O}_{2}\right)$ also play important roles as regulatory mediators in signalling processes at low concentrations. Many ROS-mediated responses protect cells against oxidative stress and re-establish redox homeostasis [2-4]. Redox homeostasis is based on redox-sensitive signalling cascades that cause an increase in the expression of antioxidant or repair enzymes, or result in the activation of the cysteine transport system, which in turn increases intracellular glutathione (GSH) in many cells. A stable redox status in cells or tissues is maintained if ROS/RNS production and scavenging capacity are essentially constant and in balance. Therefore, redox signalling requires a disturbance of this balance, either by an increase in ROS concentrations or a decrease in the activity of one or more antioxidant systems [3,5-7].

Protein oxidation is important in redox-dependent physiological signalling mechanisms [8], and is known to involve a myriad of redox-sensitive enzymes and proteins, including phosphatases, kinases, peroxiredoxins, GSH peroxidases and transcription factors $[2,3,9]$. While cysteine (Cys) redox switches are likely to be the most common, and are the best understood, there is evidence that oxidation of other residues may also contribute [10]. However, oxidation of residues such as tyrosine (Tyr), histidine (His), tryptophan (Trp) and proline (Pro), can also have deleterious effects. Some oxidative modifications such as disulfide formation or methionine sulfoxide generation can be reversed under normal conditions [11-13]. However, more extensive oxidation of Cys residues to sulfinic or sulfonic acids disrupts signalling and can be irreversible [14]. Inappropriate or excessive oxidation can result in changes (often a loss) of enzymatic activity or function, altered protein-protein interactions, protein aggregation and defective protein turnover via the proteasomal or lysosomal systems [15]. These degradation systems are also protein-dependent and subject to damage themselves [16]. All of these effects can contribute to cellular dysfunction and chronic inflammatory or neurodegenerative diseases.

Tyr residues are prime targets for oxidation by various ROS and RNS during oxidative and nitrative stress [17]. Oxidation of tyrosine, whether present as the free amino acid or as 
part of a peptide or protein, yields multiple products, with the materials generated being dependent on both the oxidant and the environment of the residue. Tyr oxidation products have been detected and quantified in a variety of tissues in order to monitor conditions of oxidative stress [18]. Individual proteins can accumulate significant levels of Tyr oxidation products, potentially affecting conformation and activity. Tyr residues are susceptible to photo-oxidative damage, which is mediated by both UVB $(\lambda 280-320 \mathrm{~nm})$ and UVA $(\lambda 320-$ $400 \mathrm{~nm}$ ) radiation [3]; the latter is likely to be more important as the majority ( $\sim 95 \%)$ of UV exposure at the surface of the earth is UVA, with only small amounts of UVB, due to the filtering effect of wavelengths lower than about $295 \mathrm{~nm}$ by the earth's upper atmosphere. As a consequence, the photochemistry of Tyr residues is also discussed. Furthermore, Tyr radicals have also been shown to be key intermediates in several enzymatic processes [19-21], and it is known that a number of enzymes contain Tyr radicals with these being essential for catalytic activity [21].

This review focuses on mechanisms of Tyr oxidation, either free in solution or as a protein residue. Methods used to assess these processes are discussed, especially with regard to proteins where technology has improved dramatically over the last few years. We consider both one-electron oxidation processes initiated by free radicals or enzyme systems, as well as two-electron reactions. As there is considerable current interest in biomarkers both for quantification of disease severity or progression, and as a surrogate in drug treatment, we review the known products arising from Tyr oxidation. Finally, the biological consequences of Tyr oxidation are explored.

\section{Mechanisms of Tyr oxidation in vitro}

\section{One-electron oxidation}

\section{Reactions of $\mathrm{Tyr}$ with ${ }^{\circ} \mathrm{OH}$ radicals}

The ${ }^{\bullet} \mathrm{OH}$-induced oxidation of Tyr, either in the presence or the absence of $\mathrm{O}_{2}$, has been examined in detail using pulse radiolysis. Approximately $85 \%$ of the primary ${ }^{\circ} \mathrm{OH}$ react to give adducts ortho- $(50 \%)$, and meta- $(35 \%)$ to the $\mathrm{OH}$-group, $5 \%$ attack the phenolic $\mathrm{OH}$ group directly, and the remaining 10\% abstract a hydrogen atom from the $\beta$-carbon [22-25]. The molar absorption coefficients and the rate constants for their formation and decay have been measured (Table 1). Rate constants for the dimerization of the ortho- and meta-adducts have been reported [22] and are summarized in Table 2. In the presence of $\mathrm{O}_{2}$, the dihydroxycyclohexadienyl radicals undergo rapid addition of $\mathrm{O}_{2}$ to yield unstable peroxyl 
radicals $\left(\right.$ Tyr- $\mathrm{O}_{2}{ }^{\bullet}$ ) (Table 2) [26]. These species decay by eliminating $\mathrm{HO}_{2}{ }^{\bullet} / \mathrm{O}_{2}^{\bullet}$, giving the hydroxylated products 3,4-DOPA or 2,4-DOPA respectively [23,27]. In contrast to these rapid processes, the direct reaction of the tyrosine phenoxyl radical $\left(\mathrm{TyrO} \mathrm{O}^{\circ}\right)$ with $\mathrm{O}_{2}$ is slow [28].

The only significant product detected by $\gamma$-irradiation of Tyr and its glycyl peptides [25] and proteins in aqueous solution at neutral $\mathrm{pH}$ has been reported to be 3,4-DOPA, possibly because of the presence of some $\mathrm{O}_{2}$ (Table 1) [29,30]. The dimeric species 3,3'-diTyr has been detected in $\gamma$-irradiated solutions of Tyr, Gly-Tyr and poly-L-Tyr, with the yield of this product dependent on $\mathrm{pH}$ and the presence of $\mathrm{O}_{2}$, with the latter suppressing diTyr formation at low and neutral $\mathrm{pH}$, but not in alkaline solution [31]. 3,3'-DiTyr has also been detected in multiple proteins, including insulin, ribonuclease, papain, collagen, and lysozyme [32-34].

\section{Reactions of Tyr with other one-electron oxidants.}

One-electron oxidation of Tyr can be initiated by multiple radicals, but with considerable variation in the rate constants (Table 1). Although not particularly biologically relevant, oxidation by ${ }^{\circ} \mathrm{N}_{3}$ has been used as a convenient mechanism for generating Tyr phenoxyl radicals, and the rate constants for free Tyr are $\mathrm{pH}$ dependent, with an increase at alkaline $\mathrm{pH}$ that is greater than for peptides and proteins [35,36]. Interestingly, it has been observed that micelles protect Tyr against oxidation by ${ }^{\circ} \mathrm{N}_{3}$, which probably relates to localization of Tyr (in aqueous phase) and ${ }^{\circ} \mathrm{N}_{3}$ (inside micelles), rather than electrostatic effects [37]. The rate constants for halogen and pseudohalogen radicals (e.g. $\mathrm{Cl}_{2}{ }^{\bullet-}, \mathrm{Br}_{2}{ }^{\bullet-}, \mathrm{I}_{2}{ }^{\bullet-}$, $(\mathrm{SCN})_{2}{ }^{--}$) with Tyr also increase with $\mathrm{pH}$ due to the increased concentration of the more reactive phenolate anion, $\mathrm{TyrO}^{-}[38]$. The reaction of chlorine dioxide $\left(\mathrm{ClO}_{2}{ }^{\circ}\right)$ is comparable to that of $\mathrm{Cl}_{2}{ }^{--}$in alkaline medium, but much slower for the protonated forms of free Tyr and $N$-Ac-Tyr [39-42]. Its reaction with Tyr residues in proteins is very slow compared to other residues [43]. Reaction with a second $\mathrm{ClO}_{2}{ }^{\bullet}$ can lead to poly-hydroxylated products $[39,44,45]$. Reactions of other inorganic radicals (e.g. $\mathrm{SO}_{4}{ }^{\bullet-}, \mathrm{HPO}_{4}{ }^{\bullet-}$, and $\mathrm{PO}_{4}{ }^{\bullet-}$ ) with Tyr and peptides containing Tyr have also been studied, and $\mathrm{pH}$-dependent rate constants and products reported (Table 1).

Nitrogen dioxide $\left({ }^{\circ} \mathrm{NO}_{2}\right)$ has emerged recently as an important biological reactant [46] and is capable of electron (or $\mathrm{H}$ atom) abstraction from Tyr to form $\mathrm{TyrO}^{\bullet}$ in a $\mathrm{pH}$-dependent manner [41], which subsequently either dimerize, or give rise to 3-nitroTyr on interaction with a second molecule of ${ }^{\circ} \mathrm{NO}_{2}$ [47]. In contrast, reaction of amino radicals $\left({ }^{\circ} \mathrm{NH}_{2}\right)$ with Tyr 
is inefficient and slow [48]. Peroxynitrite $\left(\mathrm{ONOO}^{-}\right)$, the ionized form of peroxynitrous acid $(\mathrm{ONOOH})$, does not directly react with Tyr $[49,50]$ but promotes Tyr dimerization and nitration via secondary species including ${ }^{\bullet} \mathrm{OH},{ }^{\circ} \mathrm{NO}_{2}[51]$, carbonate radical $\left(\mathrm{CO}_{3}{ }^{\bullet-}\right)$, and high oxidation state redox-active metal-centers $\left[\mathrm{Me}^{(\mathrm{n}+1)+}=\mathrm{O}, \mathrm{Me}=\mathrm{Fe}, \mathrm{Cu}\right.$, or $\left.\mathrm{Mn}\right]$ [52]. In the presence of $\mathrm{CO}_{2}$, peroxynitrite is rapidly converted to $\mathrm{ONOOCO}_{2}^{-}$, which can mediate Tyr oxidation and nitration via homolytic decomposition to ${ }^{\circ} \mathrm{NO}_{2}$ and $\mathrm{CO}_{3}{ }^{\bullet-}$ [53-55]. The local environment appears to be important in governing the ratio of nitration to dimerization products, with nitration predominating in membranes and at sites buried in the interior of proteins [56].

Peroxyl radicals $\left(\mathrm{RO}_{2}{ }^{\circ}\right)$ react rapidly with Tyr residues [57]. Lipid peroxyl radicals $\left(\mathrm{LOO}^{\bullet}\right)$ mediate one-electron oxidation of Tyr to $\mathrm{TyrO}^{\bullet}$ which react further to give $3,3^{\prime}$ diTyr 3-nitroTyr as described above [58]. Lipid alkoxyl radicals ( $\left.\mathrm{LO}^{\circ}\right)$ are more powerful oxidants readily oxidize Tyr residues. Recent measurements of the rate constant for model alkoxyl radical (tert-butoxyl radical, $t$ - $\mathrm{BuO}^{\bullet}$ ) with Tyr indicate that reaction is enhanced at alkaline $\mathrm{pH}$, consistent with a higher reactivity with $\mathrm{TyrO}^{-}$[59]. Phenoxyl radicals ( $\left.\mathrm{PheO}^{\bullet}\right)$ can also oxidize $\mathrm{TyrO}^{-}$, although this reaction is reversible [60].

\section{Photo-induced oxidation}

Photo-induced damage to Tyr residues can occur via two major pathways $[3,4,61,62]$. The first of these involves direct absorption by the amino acid and results in the generation of electronically-excited states and photo-ionized species (Figure 1). As Tyr residues only absorb weakly above $280 \mathrm{~nm}$ relative to other biological molecules and other protein sidechains (e.g. Trp), direct Tyr photo-oxidation is of limited biological relevance (reviewed in [3]). However, if the triplet state of Tyr is generated, it can undergo electron transfer reactions to yield $\operatorname{Tyr}^{\square} \bullet$ and subsequently $\mathrm{TyrO}^{\bullet}$ via rapid deprotonation $[3,61]$.

The second mode of photo-oxidation of Tyr residues involves UV or visible light absorption by endogenous (e.g. porphyrins, Trp and its metabolites, vitamins such as riboflavin) or exogenous chromophores (e.g., drugs, polyaromatic compounds and dye molecules), with singlet and subsequent triplet formation (reviewed in [3]). The latter either undergoes decay to the ground state, or further reaction to give Tyr oxidation. Type I damage involves electron or hydrogen abstraction by the triplet state to form $\mathrm{TyrO}^{\bullet}$ as above, whereas Type II damage involves energy transfer from the excited sensitizer to molecular oxygen to yield its first excited state $\left({ }^{1} \mathrm{O}_{2}{ }^{1} \Delta_{\mathrm{g}}\right.$; reviewed in $\left.[3,63,64]\right)$, which then reacts with $\mathrm{Tyr}$ 
residues (Figure 1). Indirect photo-oxidation of Tyr residues by ${ }^{1} \mathrm{O}_{2}$ is facile and fast [5,63-65] due to the relative abundance of Tyr residues on proteins compared to other ${ }^{1} \mathrm{O}_{2}$-reactive residues (e.g. Trp, Met, Cys and His; reviewed in [5,63]). However, photosensitized reactions typically proceed via a mixture of ${ }^{1} \mathrm{O}_{2}$ and radical-mediated processes [64].

Photo-oxidation of free Tyr by ${ }^{1} \mathrm{O}_{2}$ initially yields unstable endoperoxides (Figure 2). These rapidly decompose via ring opening to give a $\mathrm{C} 1$ hydroperoxide, and cyclized products involving nucleophilic addition of the $\alpha$-amino group [66-69]. Thermal decay of these intermediates gives rise to a cyclized indolic product, 3a-hydroxy-6-oxo-2,3,3a,6,7,7ahexahydro-1H-indol-2-carboxylic acid (HOHICA) [66,69]. Decomposition of the initial peroxides and cyclized products is accelerated by metal ions and UV light, and results in radical formation $[68,70]$. In peptides and proteins, the nucleophilic ring closure reactions of the $\alpha$-amino group are less favourable (due to its incorporation into a peptide bond), and consequently reaction with other nucleophiles can compete with this cyclization (A. Wright, C.L. Hawkins and M.J. Davies, unpublished data). Such addition reactions may play an important role in protein cross-link formation via Lys, Arg or Cys residues.

\section{One-electron enzymatic oxidation of Tyr}

Enzymes play important roles in protein oxidation and multiple enzymes generate radicals during their catalytic cycles, which enable Tyr oxidation [20,71]. In particular, hemecontaining enzymes catalyse free radical reactions leading to protein oxidation. Thus free hemin is able to cause oxidative cross-links in LDL, with this involving oxidation of Tyr residues on apoB-100 to 3,3'-diTyr [72,73]. Enzymatic oxidation of proteins by peroxidase enzymes and $\mathrm{H}_{2} \mathrm{O}_{2}$ also results in extensive cross-link formation involving 3,3'-diTyr and DOPA [74,75]. These reactions generate rigid structures of importance in the fertilization of sea urchin eggs, in the glues exuded by molluscs [76,77], in parasite oocysts $[12,78]$, as well as in ligninolysis [74].

Vascular peroxidase-1 (VPO1), a member of the peroxidase-cyclooxygenase family is present in the artery wall, has been reported to catalyse Tyr oxidation [79]. The peroxidative activity of $\mathrm{COX}-2$ has been reported to generate $\mathrm{TyrO}^{\bullet}$ on amyloid beta peptide [80]. On the other hand, protein 3-nitroTyr is formed by peroxidase-catalyzed oxidation of $\mathrm{NO}_{2}^{-}$, and by 'NO reaction with $\mathrm{TyrO}^{\bullet}$ to give nitrosoTyr, that is subsequently oxidized to 3-nitro Tyr [8184]. Nitration of protein Tyr by methemoglobin or hemin has been investigated, and it was concluded that methemoglobin was more effective in oxidizing protein and more toxic [85]. 
Cytochrome c has also been reported to catalyse the nitration of free Tyr in the presence of $\mathrm{H}_{2} \mathrm{O}_{2}$ and $\mathrm{NO}_{2}^{-}$[86][87]. In metmyoglobin the nitration reaction has been reported to involve formation of a $\mathrm{MbFe}(\mathrm{IV})=\mathrm{O}$ intermediate that oxidizes $\mathrm{NO}_{2}^{-}$to $\mathrm{NO}_{2}{ }^{\bullet}$ with this then nitrating the phenol ring [88]. Tyr nitration and oxidation is a hallmark of neurodegenerative diseases [89].

There is much interest in myeloperoxidase (MPO), an antimicrobial heme protein released by activated neutrophils and monocytes, and a key enzyme in inflammatory oxidant generation. Although myeloperoxidase is a major source of hypohalous acids, such as $\mathrm{HOCl}$ and $\mathrm{HOBr}$, it also generates $\mathrm{TyrO}^{\bullet}$ and $\mathrm{NO}_{2}{ }^{\bullet}$, which have bactericidal activity against invading organisms [90]. Considerable evidence implicates MPO in promoting oxidative stress in inflammatory diseases including ischemia-reperfusion injury, atherosclerosis, rheumatoid arthritis, periodontal disease and proteinuric glomerulopathies [91]. It has been reported that MPO activity, protein level and 3,3'-diTyr formation are increased in the kidneys of ad libitum fed rats during aging [92], and that MPO contributes to Tyr nitration in pulmonary and vascular inflammation [93].

\section{Reactions of TyrO}

Once formed, $\mathrm{TyrO}^{\bullet}$ can react further with other reactive species and radicals, thus expanding the range of products [94-96]; some of these reactions are illustrated in Table 2. Radical-radical reactions of $2 \mathrm{TyrO}^{\bullet}$ yields the 3,3'-diTyr dimer efficiently [97] with rate constants given in Table 2 [67]. It should however be remembered that the overall rates of all of these reactions are dependent on both the rate constants and the concentration of the reactants. This of particular importance for radical-radical reactions where the rate constants may be very large (and sometimes diffusion controlled) but the reactant species may be present at very low concentrations, resulting in a slow overall rate. Tyr dimerization occurs in protein oxidation processes in vitro and in vivo provided that the protein conformation(s) allows intra- or intermolecular reaction of the radicals, and sensitive assays have been developed for its quantitation.

$\mathrm{NO}^{\bullet}$ reacts with $\mathrm{TyrO}^{\bullet}$ in free Tyr, its $N$-acetyl derivative and Gly-Tyr (Table 2) [98]. $\mathrm{TyrO}^{\bullet}$ radicals in prostaglandin endoperoxide synthase react with ${ }^{\circ} \mathrm{NO}$ forming the nitrosocyclohexadienone intermediate, which is further oxidized to 3-nitroTyr [99]. Direct reaction of TyrO' with ${ }^{\circ} \mathrm{NO}_{2}$ represents a key pathway to the formation of 3-nitroTyr $[100,101]$, an important post-translational modification in multiple pathologies and biological 
aging [24,102-104]. Radical recombination of ${ }^{\bullet} \mathrm{NO}_{2}$ and Gly-TyrO ${ }^{\bullet}$ is $\mathrm{pH}$ dependent [100], while in proteins the reactivity of $\mathrm{TyrO}^{\bullet}$ with ${ }^{\circ} \mathrm{NO}_{2}$ appears to be reduced though there is limited data on these reactions, and they are likely to be protein-dependent; for example, in ribonucleotide reductase, nitration of Tyr121 and other Tyr residues is much slower than in dipeptides (Table 2) [105].

$\mathrm{TyrO}^{\bullet}$ reacts readily with $\mathrm{O}_{2}{ }^{\bullet-}$, predominantly via addition to the aromatic ring [67,106,107]. Electron transfer reactions, although thermodynamically feasible $[27,28,108]$, are a minor pathway $(<10 \%)$ [67]. $\mathrm{O}_{2}{ }^{\circ-}$ addition at the ortho- and para-positions yields cyclohexadienone hydroperoxides [67,109] which rapidly decompose unless they are stabilized through 1,4- or 1,6-additions of the amino group to the cyclohexadienone moiety (Figure 2A). The intermediate formed either releases $\mathrm{O}_{2}$ to regenerate parent Tyr [110], or is converted into the respective Tyr hydroperoxide [109,111]. The latter process is followed by a Michael-type addition (intramolecular cyclization) and elimination of $\mathrm{H}_{2} \mathrm{O}_{2}[112,113]$. The presence of an amino group favours hydroperoxide formation, via Michael-addition [67,106], and therefore Tyr hydroperoxides may be formed either on N-terminal Tyr residues or in basic environments (e.g. where Lys residues are in close proximity) [106], such as in Metenkephalins [27,67,114] or Boc-Met-enkephalin in which Tyr is the N-terminal residue [114] (Figure 2B). Analogous reactions on peptides or proteins occur in the presence of exogenous amines (e.g. with added ethanolamine), providing a pathway to protein hydroperoxides. Such addition reactions may be of significance when $\mathrm{TyrO}^{\bullet}$ is generated on membrane-associated protein domains exposed to lipid peroxidation, as has been demonstrated in a model system involving the hydrophobic Tyr analogue 7-methoxy-2-oxo-2H-chromen-4-yl)methyl 3-(4hydroxyphenyl) propanoate and $(6 E, 9 E)$-pentadecadiene exposed to a thermolabile azoinitiator [115]. Analogous addition products have been documented for Tyr derivatives and methyl linoleate, in addition to the formation of 3,3'-diTyr [115,116]. These reactions may not only induce protein conformational changes, but result in the formation of covalent crosslinks via subsequent reactions of the protein peroxides [16,117-119], and efficient oxidation of nearby Met residues to Met sulfoxide [111,120].

$\mathrm{TyrO}^{\bullet}$ are moderately good oxidants that oxidize thiols to thiyl radicals [121,122], though this reaction is reversible and has an equilibrium constant of $20 \pm 4$ [123]. Unpaired electron migration between aromatic and sulfur peptide units is a key process in electron transfer in proteins ([123], discussed further below), but in the absence of Cys residues or other good electron donors, such as ascorbate, $\mathrm{TyrO}^{\bullet}$ are long-lived and may undergo 
reactions with other radicals. Examples include the formation of 3'-(S-cysteinyl)Tyr crosslinks in galactose oxidase (EC 1.1.3.9) [124] (Figure 3) and cysteine dioxygenase [125]. These species may be generation via the formation of a $\mathrm{Cu}^{\mathrm{I}}$-phenoxyl radical complexes followed by homolytic disulfide cleavage into two thiyl radicals, radical-radical reaction between the phenoxyl radical and a thiyl radical [126], the addition of thiyl radicals to TyrO ${ }^{\bullet}$ followed by one-electron oxidation [127], and/or the reaction of $\mathrm{TyrO}^{\bullet}$ with thiolate, followed by one-electron oxidation $[128,129]$.

\section{Two electron oxidation of Tyr}

Heme peroxidases such as myeloperoxidase, eosinophil peroxidase, thyroid peroxidase and related species generate halogenating oxidants such as $\mathrm{HOCl}$ (hypochlorous acid), $\mathrm{HOBr}$, $\mathrm{HOI}$, chlorine $\left(\mathrm{Cl}_{2}\right)$ at low $\mathrm{pH}$, and $\mathrm{N}$-chloro and $\mathrm{N}$-bromo species from reactions of these species with amine and amide compounds, in the presence of $\mathrm{H}_{2} \mathrm{O}_{2}$ and halide $\left(\mathrm{Cl}^{-}, \mathrm{Br}^{-}, \mathrm{I}^{-}\right)$ anions. Similarly, oxidation of the pseudohalide $\mathrm{SCN}^{-}$yields $\mathrm{HOSCN}$, but other species have also been postulated [130,131]. Reaction of Tyr residues with hypohalous acids yields halogenated ring-derived species, including 3-chloroTyr, 3,5-dichloroTyr, 3-bromoTyr and 3,5-dibromoTyr. The monochlorinated species is formed relatively slowly $\left(\mathrm{k} \sim 26-50 \mathrm{M}^{-1} \mathrm{~s}^{-1}\right.$ $[40,43,132]$, with secondary halogenation being more rapid $\left(\mathrm{k} \sim 82 \mathrm{M}^{-1} \mathrm{~s}^{-1}\right.$ [40]). These rate constants increase at higher $\mathrm{pH}$ values due to the higher concentration of $\mathrm{TyrO}^{-}$. Bromination by $\mathrm{HOBr}$ is much faster than chlorination by $\mathrm{HOCl}$ (by a factor of $\sim 5000$ [132,133]). The detection of these halogenated products has been used as evidence for biological damage by heme peroxidases in vivo. Tyr chlorination by $\mathrm{HOCl}$ is proposed to involve intramolecular attack by a chloramine intermediate [40,67,134]. This reaction is optimal under acidic conditions and occurs readily in the phagolysosomal compartment of cells. 3-BromoTyr and 3,5-dibromoTyr are other major oxidative products generated by myeloperoxidase in the presence of $\mathrm{Br}^{-}[133,135]$.

The mechanism of the halogenation reactions has been studied extensively (e.g. [136]) with dispute over whether the attacking species is $\mathrm{HOCl}$, molecular chlorine $\left(\mathrm{Cl}_{2}\right)$ (and corresponding trans-halogen species [135]), enzyme-bound species (for the enzyme-catalysed reactions), and amine-derived N-chloro [137] or N-bromo species (in the case of $\mathrm{HOBr} /$ eosinophil-mediated reactions [138]). Studies at low $\mathrm{pH}$ have provided data supporting an involvement of $\mathrm{Cl}_{2}$ (and related species) [135,139], but at neutral $\mathrm{pH}$ it is likely that $\mathrm{HOCl}$ and N-halogen species are involved (i.e. formally $\mathrm{Cl}^{+}$; though this is unlikely to be a free species [136]). Reaction of protein Tyr residues with HOSCN has also been reported [140] 
with this attributed to $(\mathrm{SCN})_{2}$ rather than $\mathrm{HOSCN}$, although the involvement of $(\mathrm{SCN})_{2}$ is disputed. For free Tyr alternative pathways predominate, as reaction of the free amine with $\mathrm{HOCl}$ and $\mathrm{HOBr}$ is more rapid than ring halogenation (cf. rate constants in [132]) with this resulting in the formation of N-chloro / N-bromo species. These semi-stable species undergo dehydrohalogenation reactions to give p-hydroxyphenylacetaldehyde, which can subsequently form adducts with other proteins [139,141-143].

\section{Role of Tyr residues in long range intra- and intermolecular electron transfer in amino acids, peptides and proteins}

Electron transfer (ET) processes involving Tyr residues have been demonstrated both in aqueous and non-aqueous solvents by using model peptides and proteins after selective oxidation of redox-active amino acids residues (e.g. Trp, Met, His, Cys) [144,145]. For example, peroxynitrite and peroxynitrite/bicarbonate-mediated nitration and oxidation of Tyr in Tyr-Met peptide can be stimulated by the presence of a Met residue. Intramolecular electron transfer from the Tyr residue to the Met sulfide radical-cation is proposed to account for enhanced Tyr nitration and oxidation [146].

The reduction potential of the $\mathrm{TyrO}^{\bullet} /$ Tyr redox couple has been measured to be in the range $\mathrm{E}^{0}\left(\mathrm{TyrO}^{\bullet}, \mathrm{H}^{+} / \mathrm{TyrOH}\right)=(0.85-0.94) \pm 0.02 \mathrm{~V}$ vs. NHE at $\mathrm{pH} 7$. It shows a marked $\mathrm{pH}$ dependence [147,148] and small differences are observed with substituted Tyr, or Tyr in peptides [149]. Time-resolved studies of Tyr in several model systems and native/modified proteins have provided evidence for the inter- and intramolecular radical transformations (summarized in Figure 4) involving Trp [35,150], Cys [123], His [151,152] and various Metderived radicals $[100,153,154]$. Many factors influence these reactions, with rate constants for IET ranging from $<10^{2}$ to $>10^{7} \mathrm{~s}^{-1}$, but the kinetic diversity can be mostly explained by Marcus theory [155]. However, in some cases the structure of the peptide matrix has to be taken into account [156].

Redox-active Tyr residues play an important role in long-range electron transfer (LRET) in native biological processes [157-159]. TyrO ${ }^{\bullet}$ have been postulated to mediate LRET in enzymes including prostaglandin H synthase (EC 1.14.99.1) [160], galactose and cytochrome c oxidases [161,162], ribonucleotide reductase (RNR; EC 1.17.4.1) [163], photosystem II (PSII) [164] and DNA photolyase [165]. It has also been suggested that electron transfer (ET) involving Tyr residues is responsible for the activation of voltagesensitive ion channels [166]. In most of these systems, Tyr residues can act as relay amino 
acids in ET reactions, since the reduction potential of $\mathrm{TyrO}^{\bullet}$ is very low and thus allows facile redox processes [158]. Moreover, the possibility for a proton shuttle should exist in order to regenerate the Tyr radical-cation $\left(\mathrm{Tyr}^{+\bullet}\right)$ needed for the subsequent ET.

Two well-characterized examples are photosystem II (PSII) and ribonucleotide reductase (RNR) [158]. PSII contains two adjacent redox-active Tyr residues, Tyr160 and Tyr161, with the latter directly involved in a proton-coupled ET processes [167]. The other Tyr residue, Tyr160 appears to be indirectly involved in controlling ET in PSII either by the presence of Tyr160- $\mathrm{O}^{\bullet}$ which increases oxidizing properties of $\mathrm{P} 680^{+}$[168] or by structurally affecting the redox properties of Tyr161 [169]. Two neighboring amino acids, Gln164 and His189, might be involved in a proton shuttle to make Tyr160 a relay amino acid [170]. Involvement of peptide bonds in $\mathrm{TyrO}^{\circ}$-based ET reactions has been also demonstrated in PSII [171,172]. In RNR I, the active cysteine thiyl radical is generated on Cys439 by an ET over a distance of $35 \AA$ to a $\mathrm{TyrO}^{\bullet}$ formed at Tyr122 by a diferric cofactor [163]. This LRET can be rationalized by a multistep electron hopping mechanism, where electrons shuttle between the aromatic side-chains of a number of amino acids in a relay system including Tyr356 [163]. A further example of this involves the repair of a $\mathrm{TyrO}^{\bullet}$ in some isoforms of superoxide dismutase B (e.g. Fe-SOD-B) by remote Cys residues $[173,174]$. In order to test such a "relay amino acid" concept in LRET, a family of nonapeptides consisting of a Tyr residue as an efficient electron donor at the $\mathrm{N}$-terminal end, a dialkoxyphenylalanine as an electron acceptor, and a third amino acid (X) with a side chain that might act as a relay amino acid, have been designed and used for the study of intramolecular electron transfer processes and for probing the role of various amino acids residues (Met, Cys, Trp) [158,175-177].

\section{Established and novel detection methods for oxidized Tyr in vitro and in tissues}

\section{Time-resolved methods}

The time-resolved techniques such as flash photolysis and pulse radiolysis are powerful techniques for obtaining quantitative information concerning reaction kinetics and spectral properties of free radicals in solutions [178]. Free radicals are produced either via electronic excitation of molecules by very short pulses of UV/Vis radiation or ionization of solvent or solute molecules by high-energy electrons $(>1 \mathrm{MeV})$ [4]. Various analytical techniques can be used to quantify and identify these products. For radicals in solution, the most commonly used technique is time-resolved UV-vis spectroscopy [179], however, time-resolved 
conductivity [180], electron paramagnetic resonance [181], vibrational resonance Raman spectroscopy [182], microwave absorption spectroscopy [183,184], polarography, circular dichroism [185], and, infrared spectroscopy [186], can also be used to provide kinetic, spectral, and mechanistic details that are not accessible via absorption measurements.

\section{Spectroscopic methods of quantifying Tyr oxidation products}

NMR spectroscopy has been used to analyse and confirm the structure of a number of Tyr oxidation products including DOPA [187] and species generated by singlet oxygen [68], but this method is limited to relatively clean systems, and is not a method of choice for complex systems, or even for some intact proteins, due to the large number of overlapping resonances that prevent identification of low levels of oxidative modifications. This technique has, however, proved to be very useful in other cases, including assessment of the translational incorporation of DOPA residues into proteins [188].

Electron paramagnetic resonance (EPR) spectroscopy (and related techniques such as Electron Nuclear DOuble Resonance, ENDOR) has been used extensively to provide direct evidence for $\mathrm{TyrO}^{\bullet}$ formation from free Tyr, and Tyr within peptides and proteins. The wealth of detail afforded by the hyperfine couplings of the (delocalized) unpaired electron has allowed detailed analysis of the electron distribution in these species (and how this is affected by local structure / neighbouring residues [189]), the conformation of the ring relative to the methylene $\left(-\mathrm{CH}_{2}-\right)$ group linking the ring to the backbone $[190,191]$ and peptide conformations. The ortho and meta ring proton couplings show only small variation for neutral radicals, but the methylene proton couplings vary dramatically on altering the rotation angle between the (planar) aromatic ring and the $\mathrm{C}-\mathrm{H}$ bonds allowing exquisite detail to be obtained with regard to the orientation of the phenoxyl radical ring relative to the surrounding protein backbone [190]. The variation in these couplings has allowed multiple different radical sites on different $\mathrm{TyrO}^{\bullet}$ to be elucidated in proteins [191]. Examples include Tyr radicals formed on myoglobin [61,192-194], haemoglobin [194,195], leghemoglobin [196,197], cytochrome c [198], prostaglandin synthase [99,160,199-201], in photosystems [191,202,203], galactose oxidase [161], and various ribonucleotide reductases [72,191,204]. Data on the rates and barriers to rotation have also been obtained for free $\mathrm{TyrO}^{\bullet}[190]$. Tyrderived radicals have also been detected by EPR spin trapping, in which TyrO ${ }^{\bullet}$ is trapped, using nitroso or nitrone compounds, to give longer-lived radicals adducts where the adducted radical can be identified on the basis of the hyperfine coupling constants $[5,193,205,206]$. 
Whilst this technique has some advantages over direct detection, not all radicals are rapidly trapped, and hence the absence of an adduct signal does not necessarily equate to the absence of a radical [5].

Raman (including UV resonance Raman) and infra-red spectroscopy have been used to detect and identify $\mathrm{TyrO}^{\bullet}$ on peptides and proteins, particularly in situations where these are relatively long-lived and / or on isolated proteins or in purified fractions. These techniques are of particular value in examining the ionization state of the -OH group, the presence and nature of hydrogen bonding with this function [207-209], and the conformation of the phenol with regard to the surrounding protein / peptide structure [19]. These methods have also been used extensively to examine $\mathrm{TyrO}^{\bullet}$ in photosystems (e.g. [210,211]) and plastoquinones [211]. Moreover, these techniques have helped elucidate Tyr oxidation in beta-amyloid peptide [212], the formation of oxidation products that have distinctive bands such as quinones, and metal ion complexes with these species [209,213].

\section{Redox staining methods}

DOPA and quinone formation in proteins and tissues has been examined using a redox staining approach using nitroblue tetrazolium and glycine as a reductant at high $\mathrm{pH}[214,215]$. Redox cycling of these quinones, catalyzed by glycine, results in the reduction of the tetrazolium salt to (insoluble) formazan. This process can be applied to proteins separated by 1- or 2-D SDS-PAGE allowing proteins containing quinones to be detected (and subsequently identified by mass spectroscopic sequencing techniques). This approach has also been used to examine proteins with quinone co-factors, and also the biosynthetic incorporation of DOPA in to new proteins by cells [216].

\section{Colorimetric assay of Tyr hydroperoxides}

Hydroperoxides and related peroxides can be (at least semi-) quantified using the FOX (Ferrous $\underline{\text { Oxidation- } \underline{X} y l e n o l}$ orange) assay. This method utilizes hydroperoxide-mediated oxidation of a $\mathrm{Fe}(\mathrm{II})$-xylenol orange complex to the Fe(III) form, with spectrophotometric quantification at $560 \mathrm{~nm}$ [217]. The Fe(II)-xylenol orange complex reacts with many peroxides and there is little distinction, apart from kinetically, between different peroxidic species. It therefore cannot distinguish between different Tyr hydroperoxides (e.g. ring isomers), and care needs to be taken to remove $\mathrm{H}_{2} \mathrm{O}_{2}$ (e.g. using catalase) that confounds measurements. However, the time period needed to remove $\mathrm{H}_{2} \mathrm{O}_{2}$ may also result in Tyr hydroperoxide decomposition. Furthermore, the stoichiometry of peroxide reaction with 
Fe(II)-xylenol orange is not always well established, and is known to vary [217]. As a consequence, only relative data can be obtained, with values typically reported as $\mathrm{H}_{2} \mathrm{O}_{2}$ equivalents. This method has been used to examine peroxides formed by ${ }^{1} \mathrm{O}_{2}$-mediated oxidation of free and protein Tyr residues $[68,70]$, and peroxides from reaction of $\mathrm{O}_{2}{ }^{-}$with $\mathrm{TyrO}^{\bullet}$ and related species [106,107,218]. Hydroperoxides can also be assayed by potassium permanganate- and iodometric-titrations [219]. For heterogenous systems (e.g. those containing lipid hydroperoxides), assays have been developed in which the lipid and protein components are separated before quantification [220].

\section{Antibody-based analytical techniques}

Antibody-based methods such as ELISA and Western blotting are widely employed due to their ease of use, but they depend on the availability of antibodies selective for the analyte of interest. Tyr oxidation products are typically detected by use of antibodies that recognize them directly, though not all antibodies are validated for all procedures. For example, some antibodies developed initially for immunocytochemistry (ICC), immunohistochemistry (IHC) or Western blotting are not suitable for immunoassays or immunoprecipitation. Immunostaining approaches such as IHC and ICC provide information on spatial localization and cellular or tissue occurrence of Tyr oxidation, while Western blotting offers more information on the proteins modified (though see also below). However, these methods are semi-quantitative at best, dependent on scoring of stain intensity or densitometry. In contrast, immunoassays such as ELISAs generate a numerical output and use of appropriate standard curves allows assessment of total levels of Tyr oxidation, although there may be a number of complicating factors.

One of the earliest reports of an ELISA for 3-nitroTyr was a competition assay involving immobilized antigen (nitrated BSA) and a polyclonal anti-3-nitroTyr from rabbit (TCS Biologicals, Bucks, UK) in solution with the sample [221]. The polyclonal antibody was reported to have low affinity for 3-chloroTyr, phosphoTyr, 4-nitrophenylalanine or free 3-nitroTyr; it also discriminated against 3-nitroTyr in different peptides, but consequently was only semi-quantitative with mixtures of proteins. However, a sandwich ELISA using two mouse monoclonal IgG clones (HM.11 and HM.12) was subsequently reported to be more specific [222]. The HM.11 clone is commercially available, and all of these antibodies are compatible with immunoblotting. Franze et al. have compared several anti-3-nitroTyr antibodies for use in immunoassays for nitrated proteins, and concluded that sandwich assays were better than one-sided assays, owing to less interference from native proteins [223]. 
These assays are very sensitive, with limits of detection in the picomolar range. A solid phase ELISA, involving binding to a nitrocellulose membrane and detection by ${ }^{125} \mathrm{I}$-labelled $\mathrm{IgG}$ as the secondary antibody and beta-counting for quantification has also been used in studies on infants with bronchopulmonary dysplasia [224] and carbon monoxide-exposed endothelium [225]. More recently, a custom ELISA microarray platform for 3-nitroTyr analysis in clinical plasma samples has been reported, which uses a biotinylated antibody (from Hycult Biotechnology) [226]. These applications are summarized in Table 3.

Western blotting has been used extensively to examine protein-bound 3-nitroTyr, [226-228]. Detailed protocols have been published [229], and the efficiency of separation can be increased by use of 2D gel electrophoresis followed by MS detection, as described below. Appropriate choice of conditions for immunoblotting, and in particular the absence of reducing agents such as DTT, is important, as 3-nitroTyr can be converted to 3-aminoTyr in the presence of DTT and heme proteins, and this may contribute to signal loss [230]. Interestingly, Dragusanu et al. investigated the nitropeptide binding affinities of the mouse mAb MAB5404 from Chemicon International (Switzerland), and found that binding was enhanced by the presence of arginine or lysine positioned 2 to 3 residues away from the 3nitroTyr on the N-terminal side, showing that antibody responses to proteins may be sequence-dependent [231].

In contrast to many studies on 3-nitroTyr, much less attention has been paid to other Tyr modifications. A monoclonal antibody against KLH conjugated to 3(p-hydroxyphenyl) propionic acid dimer (i.e. an analogous cross-link to 3,3'-diTyr) has been and used to demonstrate the presence of 3,3'-diTyr in atherosclerotic plaques by Western blotting [232]. This antibody has also been used in immunoblotting experiments to show that copper can induce 3,3'-diTyr cross-links in $\beta$-amyloid [233], and in RANTES and IL-8 [234]; the mAb and ELISA kit are commercially available from JaICA.com. More recently, a mAb that recognizes protein-bound 3,5-dihalogenated Tyr, and especially 3,5'-dibromoTyr, has been reported; this species does not recognize mono-halogenated forms and other modifications such as 3-nitroTyr [235,236]. These antibodies have been used both in ELISAs and in IHC of mouse liver following exposure to lipopolysaccharide [236].

\section{Mass spectrometry}

A major challenge in analysing Tyr oxidation is to determine the exact sites of modifications in proteins, with the only routine method being mass spectrometry. This is critical, because otherwise the protein modified cannot be identified with confidence. For 
example, a band or spot on a gel may stain positively with anti-oxPTM antibodies in Western blot experiments, but parallel analysis of the band or spot by peptide mass fingerprinting may identify several proteins present at that location, and the modified protein may not necessarily be that with the highest abundance. Therefore most other methods, such as Western blotting or chromatography, are at some stage interfaced or integrated with MS analysis.

The procedure is briefly summarized in Figure 5. Most work has been carried out on Tyr nitration, although research has been carried out on chlorination and hydroxylation. For 3-nitroTyr, the methods can be divided into label-free and label-dependent approaches; the latter can be used to both selectively separate 3-nitroTyr containing species and to provide fragmentation patterns to facilitate MS identification. The most routine methodology involves identifying proteins present in bands of $1 \mathrm{D}$ gels, or spots in 2D gels by peptide mass fingerprinting, usually carried out by MALDI-TOF MS, and confirming the presence of 3nitroTyr by the addition of +45 a.m.u. to the peptide mass, relative to the mass of the unmodified peptide containing Tyr. However, the laser excitation used in MALDI can lead to loss of either 1 or 2 oxygen atoms from the nitro group to form 3-nitrosoTyr or 3-nitreneTyr respectively. While this has potential as a diagnostic signal for 3-nitroTyr, it also reduces the signal intensity of the +45 species and therefore the sensitivity of the method $[81,237]$. This fragmentation is not observed with electrospray ionization, where nitrated peptides or fragment ions containing 3-nitroTyr are only observed at +45 a.m.u compared to the native peptide and fragment ions. This approach is relatively straightforward for purified proteins, such as in a study of $\mathrm{ONOO}^{-}$-oxidized GroEL where nitrated peptides were confirmed as containing 3-nitroTyr using collision-induced dissociation MS/MS [238]. Vana's group carried out detection of 3-nitroTyr in isolated tau and mutant tau proteins nitrated in vitro by this approach, with MS/MS sequencing [239-241]. It has also been used to study protein nitration in Arabidopsis thaliana [242]. The delayed elution in reverse phase chromatography of nitrated peptides, which are more hydrophobic than the non-modified peptides, can be useful in identifying 3-nitroTyr-containing peptides.

Analogous label-free but untargeted approaches have been used to detect both 3chloroTyr and DOPA on the apo-AI protein of HDL [243,244]. In the former case, 3chloroTyr was detected on human apo-AI protein treated with $\mathrm{MPO}-\mathrm{H}_{2} \mathrm{O}_{2}-\mathrm{Cl}^{-}$; tryptic peptides were analysed by LC-ESI/MS/MS and Tyr chlorination was identified by a mass increase of 34 a.m.u., with chlorination reported to occur preferentially at Tyr 192 [245,246]. More recently, selected reaction monitoring using specific transitions for the peptide containing Tyr192 (LAEYHAK) have been used to demonstrate the presence of 3-nitroTyr on 
apoA-1 isolated from human plasma HDL and atherosclerotic lesions. DOPA, and its oxidation product dopaquinone, were detected in mouse brain and heart tissues by LCMS/MS analysis [244]. An initial fractionation using a strong cation exchange column was carried out before nano-LC-MS/MS, and the data were searched for 3-nitroTyr, DOPA, and dopaquinone by applying dynamic modifications of 44.9851, 15.9949, and 13.9793 Da on Tyr residues, respectively. DOPA and dopaquinone modifications were found to be more abundant than 3-nitroTyr. DOPA modified peptides were also detected in E. coli and HeLa cell mitochondria using similar methods [247,248]. PTMap, a sequence alignment software for unrestricted, accurate, and full-spectrum identification of post-translational modification sites, was used to identify DOPA-containing peptides before manual validation [247]. These authors also reported a high abundance of proteins containing DOPA $(2.5 \%$ in E. coli and $0.5 \%$ in HeLa mitochondria), whereas 3-nitroTyr containing peptides only represented $0.00001-0.001 \%$ of total proteins [249].

In label-free approaches for protein nitration, the occurrence of the 3-nitroTyr immonium ion at $\mathrm{m} / \mathrm{z} 181.06$ is often used as an additional marker in the $\mathrm{b}$ and $\mathrm{y}$ ion series spectrum to confirm the presence of 3-nitroTyr. It can also be used for targeted scanning routines such as precursor ion scanning. Such an approach is important for analysis of complex mixtures, as it is very difficult to undertake manual sequencing to confirm nitroPTMs on numerous proteins. Precursor ion scanning involves peptides containing the modification of interest fragmenting to give a diagnostic $\mathrm{MS}^{2}$ daughter ion whose detection indicates the presence of the oxPTM in the parent ion. Petersson et al. nitrated angiotensin II and bovine serum albumin in vitro with tetranitromethane, and the formation of 3-nitroTyr was detected by precursor ion scanning for the 3-nitroTyr immonium ion at $m / z 181.06$ [250]. The site of modification was confirmed by peptide sequencing, which can also identify the source protein. However, it should be noted that precursor ion scanning at low resolution may result in false positives owing to the occurrence of isobaric ions and a protocol for confirming 3-nitroTyr is recommended [251]. Similar problems with $\mathrm{MS}^{2}$ precursor ion scanning for 3nitroTyr have been reported [10,252], but an $\mathrm{MS}^{3}$ strategy could be used to obtain more specific diagnostic fragment ions for 3-chloroTyr, DOPA, 2-hydroxytryptophan and 5hydroxytryptophan. Alternatively, high resolution selection of product ions in pseudoprecursor ion scanning on accurate mass instruments offer improvements for the analysis of both 3-chloroTyr and 3-nitroTyr [253].

In view of the possibilities for misidentification, data analysis software tools for stringent data handling and avoidance of false positives are important especially with label- 
free methods [254]. One example is Peptizer software, which works on "agents" constructed from diagnostic ion and MS parameter rules [255]. The use of a set of 3-nitroTyr peptides from 48 proteins as standards to optimize methodology has been proposed [256]. It is important to note that the fragmentation method used influences the ability to detect modifications. ECD fragmentation is not as good for nitrated peptides as slow heating fragmentation methods (e.g. CID), especially for $2+$ charge states, although it has advantages for top-down analysis of proteins [257,258].

Even with targeted MS methods, the detection of Tyr modifications is difficult due to their low abundance and the high background of unmodified proteins. Many groups have attempted to enrich peptides and proteins containing oxidative modifications, with most effort (and success) directed at 3-nitroTyr. Although immunoprecipitation (IP) methods with anti-3nitroTyr antibodies have been used, these have not always proved effective [259]. Other enrichment methods have been developed, involving the specific labelling of 3-nitroTyr with tags that allow separation of nitropeptides by solid phase extractions. The first stage in all of these procedures is the reduction of 3-nitroTyr to 3-aminoTyr, a more chemically reactive group that can be derivatized with different reagents [260]. Many different labelling strategies have been tested, and are summarized in Table 4. These methodologies are reported to improve the detection levels and sensitivity, and often reduce the false discovery rate, as reported for example in mouse brain homogenate [261].

Overall, label-free MS methods for various oxPTMs have the advantage of simplicity, but depend on targeted scanning methods. Enrichment methods have only been developed to a major extent for 3-nitroTyr, but these do increase coverage and detection in complex mixtures, and some also provide convenient diagnostic fragment ions for targeted MS methods [262-264]. With all approaches, meticulous examination of the sequence data is required, standards are ideally required [256] and approaches for verification, at least for 3nitroTyr, have been suggested [254]. A final caveat that needs to noted, when using reduction of 3-nitroTyr to 3-aminoTyr, is the assumption that the proteins containing 3-aminoTyr correspond to those that contained 3-nitroTyr in vivo. This may not always be the case. For example, 3-aminoTyr in plant extracts was identified using a label-free approach, suggesting that this material may occur naturally [242].

\section{Tyr oxidation and nitration in vivo}

The availability of antibodies against 3-nitroTyr, together with the MS techniques described above, have resulted in many studies on the contribution of Tyr oxidation, 
halogenation and nitration to pathologic processes (Table 3), including neurodegenerative diseases [265,266], cardiovascular dysfunction [267,268] and cancer [269-272]. Some proteomic studies have provided extensive lists of protein targets for Tyr oxidation and nitration in vivo [81,244]. A key question arising from many of these studies is whether Tyr modification is causal in these processes, or merely a consequence (bystander) without biological function. Oxidants which modify Tyr (e.g., peroxynitrite and $\mathrm{HOCl}$ ) usually also react with other amino acids (e.g., Cys and Met) and it is not sufficient to merely document oxidation or nitration of Tyr on a protein in order to correlate Tyr modification with biologic function. An interesting example is the controversy surrounding apoA-I activation of lecithin:cholesterol acyltransferase (LCAT), where separate studies reported on the critical role of Tyr chlorination and Met oxidation [273]. However, while the extent to which the oxidation and/or nitration of individual amino acids contributes to protein dysfunction in specific cases may be uncertain, the accumulation of oxidized and nitrated proteins per se may be of clinical relevance. Several studies have evaluated Tyr nitration in specific cancers, and revealed a correlation between nitration and clinical prognosis, including long-term survival [271]. One possible rationale for this association may be nitration of specific chemokines, which negatively impacts on leukocyte recruitment to tumors, i.e. a weakening of the immune response towards cancer cells [272].

\section{Repair of oxidized Tyr compounds \\ Repair of $\mathrm{TyrO}^{\circ}$ by various systems in vitro}

Repair of $\mathrm{TyrO}^{\bullet}$ by reductants such $\mathrm{AscH}^{-}, \mathrm{GSH}, \mathrm{Cys}, \mathrm{GSeH}, \mathrm{SeCys}$, urate, and Trolox have been observed for both free Tyr, and Tyr in peptides and proteins [34,128,274278]. Ascorbate anions reduce free $\mathrm{TyrO}^{\bullet}$ effectively and the rate constants for reaction with GSH, urate and Trolox have been determined both for model compounds and proteins [274276]. The variations are typically small, indicating that the location of $\mathrm{TyrO}^{\bullet}$ in the protein chain is not a significant barrier to reaction with ascorbate [34].

Table 5 summarizes data for a range of species including $N$-Ac-Tyr- $\mathrm{NH}_{2}$ and insulin, with GSH, Cys, GSeH and SeCys. For protein $\mathrm{TyrO}^{\bullet}$ (e.g. in insulin) there is a significant reduction in reactivity ( 3 and 2 orders of magnitude) compared to free $\operatorname{TyrO}^{\bullet}$ [278]. Dimerization of $\mathrm{TyrO}^{\bullet}$ was inhibited by cysteine or $\mathrm{O}_{2}$, consistent with $\mathrm{TyrO}^{\bullet}$ repair by cysteine $\left(\mathrm{TyrO}^{\bullet}+\mathrm{Cys} \rightarrow \mathrm{TyrOH}+\mathrm{Cys}^{\bullet}\right.$ ) or $\mathrm{O}_{2}{ }^{\bullet-}$ (either via addition to give a hydroperoxide or electron transfer; see above) [108]. Cys and GSH react more slowly (3 and 5 orders of 
magnitude slower) than their selenium analogues with $\mathrm{TyrO}^{\bullet}$ [278]. Conversely, the rate constants for repair of $\mathrm{TyrO}^{\bullet}$ by urate do not vary significantly between proteins [277]. In contrast, Hoey et al. showed that repair of protein-bound $\mathrm{TyrO}^{\bullet}$ varies strongly with the protein [275]. The quantitative data in Table 5 are in agreement with numerous qualitative studies.

\section{Biochemical detoxification of 3-nitroTyr}

For a PTM to have significance as a regulatory mechanism, there must be a biochemical process for reversal of the modification, ideally a rapid one. For many years, Tyr oxidation products were considered as stable PTMs because many are relatively chemically inert, though DOPA is a notable exception. However, a number of studies have provided evidence for cellular detoxification of modified proteins, with most studies focusing on denitration, though dechlorination has also been reported. Some early work suggested that nitrated proteins, generated by peroxynitrite, were preferentially degraded proteolytically [279]. Later, the hypothesis that denitration could occur stemmed from the observation that 3-nitroTyr detection by immunoassay decreased after incubation of nitrated protein with human plasma or homogenates of rat brain, liver or lung, and appeared to be time- and temperaturedependent and could occur without protein degradation [280]. This observation has been confirmed in other tissues, and it has been reported that the process is inhibited by heat or protein filtration, but is insensitive to proteasomal inhibitors such as lactacystin (reviewed in [81]), providing support for the concept of 3-nitroTyr metabolism.

Enzymatic removal of 3-nitroTyr could result either from denitration or from reduction to 3-aminoTyr (see above), and evidence has been reported for both processes. Chen et al. reported that lipoyl dehydrogenase could reduce free 3-nitroTyr to 3-aminoTyr [281], and subsequently showed using CID MS, that 3-nitroTyr in proteins can be reduced to 3-aminoTyr by metalloproteins, GSH and ascorbate [281]. It has also been reported that free nitrate can be released from protein 3-nitroTyr by an E. coli nitrate reductase, or a mammalian cytochrome P450 [282], based on Western blotting for 3-nitroTyr, though this was not confirmed by MS. Similar approaches subsequently identified mitochondrial nitration and denitration activity [283] and a lipoprotein-associated denitration activity [284]. These immunoassay studies are not necessarily conclusive, as loss of antibody recognition could be due to further protein modification rather than denitration. Consequently FTICR MS was used to confirm nitration and denitration of calmodulin during macrophage activation, providing 
more robust evidence for denitration [285]. It appears that there are both $\mathrm{O}_{2}$-dependent and independent denitration processes. It has been suggested that in mitochondria the cycle of nitration and denitration is target specific, and could act as a signalling mechanism responsive to $\mathrm{O}_{2}$ levels [283]. Similarly, denitration of an L-type Ca channel by LPS-activated RAW264.7 cell lysates has been suggested as a physiological mechanism to regulate cellular excitotoxicity [286].

GC-MS studies have shown that free 3-chloroTyr can be metabolized in rats to 3chloro-4-hydroxyphenylacetic acid via further oxidation of the amino group [143], and dechlorination of modified albumin by liver homogenates was also reported [287]. Thus whilst evidence for metabolism of oxidatively-modified Tyr is increasing, a critical question remains with regard to whether denitration and dechlorination restores native protein activity, which would be critical for a regulatory cycle [281].

\section{Biological consequences of oxidation of Tyr in proteins}

\section{Structural and functional consequences of Tyr oxidation}

Modification of Tyr in proteins may result in alterations of protein structure and dynamics, potentially accompanied by changes in protein turnover (depending on the degree of modification), protein-protein interaction, polymerization, and/or protein activity $[18,103,288]$. Crystallographic studies have reported slight to significant structural alterations when Tyr residues are converted to 3-nitroTyr. Thus, nitration of Tyr34 in human manganese superoxide dismutase (MnSOD; SOD2; EC 1.15.1.1) results in a new hydrogen bond between an oxygen atom of the nitro group and the side chain amide of Gln143 [289]. However, comparison of the structures of nitrated and native human MnSOD reveals that the aromatic rings of Tyr34 and 3-nitroTyr34 nearly overlap, indicating little conformational change. In contrast, for human glutathione reductase, Tyr nitration results in a significant conformational change with the aromatic ring of 3-nitroTyr 114 rotated by ca. $60^{\circ}$ compared to the parent residue in the native protein [290].

An unusual Tyr modification, 3'-(S-cysteinyl)Tyr, is present in galactose oxidase (EC 1.1.3.9) [124] (Figure 3) and human cysteine dioxygenase (EC 1.13.11.20) [125]. This modification may be formed via reaction of $\mathrm{TyrO}^{\bullet}$ with Cys thiyl radicals [126], the addition of thiyl radicals to Tyr followed by one-electron oxidation [127] and/or the reaction of Tyr radicals with thiolate, followed by one-electron oxidation [129]. The significance of the thioether bond in 3'-(S-cysteinyl)Tyr has been addressed in a series of studies [126,291-293]. 
It appears that the thioether ligand affects both the O-H homolytic bond dissociation energy (BDE) and the reduction potential of the substituted phenol, and affords significant delocalization of the spin of the oxidized amino acid, the 3'-(S-cysteinyl)Tyr radical, onto the sulfur. Two conformers of model 3'-(S-alkyl)phenols showed different O-H BDEs, with this depending on whether the alkylthio substituent is oriented in-plane or out-of-plane relative to the aromatic ring system [291], with this having has significant consequences for the phenoxyl radical-stabilizing propensities of the thioether ligand. It has therefore been proposed that galactose oxidase can fine-tune its catalytic properties through minor conformational changes around the thioether substituent [291].

$\mathrm{Ca}^{2+}$-ATPases, especially the sarco/endoplasmic reticulum $\mathrm{Ca}^{2+}$-ATPase (SERCA; EC 3.6.3.8), offer good examples to illustrate the effects of Tyr nitration and oxidation. The physiological role of SERCA is to sequester cytosolic $\mathrm{Ca}^{2+}$ into sarco/endoplasmic reticulum (SR/ER), which plays a key role in maintaining intracellular $\mathrm{Ca}^{2+}$ levels within the physiological range [294,295]. There is evidence that redox regulation of SERCA is important in vascular relaxation and in ageing heart and skeletal muscle; nitration of vicinal Tyr294 and Tyr295 (Figure 6) on the lumenal side of the membrane-spanning helix M4 was observed, which correlated with partial inhibition [296,297]. It has been concluded that peroxynitrite inactivates SERCA1 via both Cys oxidation and Tyr nitration [298]. The predominant nitration of Tyr122 was confirmed in the SERCA sequence at a molar ratio of 3-nitroTyr to protein of 0.23 [299]. Tyr nitration induces a dramatic decrease in the $\mathrm{pKa}$ of Tyr phenolic group (from 10 to 7.2) and Tyr294 and Tyr295 are in close proximity to a negatively-charged amino acid side chain. When nitrated, this cluster of three negative charges may distort helixhelix interactions at the M4-M5 interface and further hinder the coordinated movements of membrane helices required for optimal rates of active transport by the $\mathrm{Ca}^{2+}$-ATPase. This nitration of Tyr and resulting changes in conformation are consistent with a partial decrease of ATPase activity, and suggests that nitration has a regulatory effect rather than merely reflecting protein damage [300].

One notable feature of SERCA2a nitration is the limited number of the 18 Tyr residues that are nitrated both in vivo and in vitro. It was shown that lipid-soluble Tyr are nitrated $\sim 10$-fold more efficiently than those in the aqueous phase [301]. Nitration of Tyr has been observed to be more frequent in the vicinity of positive charges, on Lys, Arg, and the amino terminus, than in the absence of these residues [302], consistent with electrostatic attraction between basic amino acids and nitrating species such as nitrosoperoxycarbonate or $\mathrm{CO}_{3}^{-\cdot}[303]$. 


\section{Interference with phosphorylation pathways}

Tyr phosphorylation is a key process in signal transduction, and modification of Tyr residues in receptor molecules has been shown to impair signalling pathways and cell regulation processes [304]. Nitration can therefore potentially compromise the phosphorylation / dephosphorylation cycle of Tyr [276]. Evidence for this has been obtained from studies on the nitration/oxidation of Tyr in model substrates, with this preventing phosphorylation by protein Tyr kinases [280,305]. Nitration may lock some enzymes into inactive forms (although this may be reversible, see above), but the overall extent of Tyr nitration appears to be rather low. Another protein thought to be affected by Tyr nitration is the platelet-derived growth factor (PDGF) receptor, which has five Tyr autophosphorylation sites [306,307]. Mutation or modification of these residues can block signalling; in particular, nitration of Tyr1009 and Tyr1021 prevents the binding and activation of phospholipase Cgamma (PLC-gamma), an important signalling protein [308]. If PLC-gamma does not bind to the Tyr residues, the inositol phospholipid signalling pathway is not activated. Conversely nitration and dimerization (via 3,3'-diTyr) of epidermal growth factor induced by peroxynitrite, did not significantly affect its autophosphorylation [309]. Furthermore, the phosphorylation of the dimers was more extensive. Other important receptors, such as the insulin receptor also contains key Tyr residues that can be phosphorylated and which may become inactivated by nitration [310]. Intermolecular cross-linking of enzymes involved in signal transduction via 3,3'-diTyr formation has also been detected in cells [309]. On the other hand, there has also been a report that 3-nitroTyr substitution into Tyr-containing peptides mimicking the C-terminus of src kinases or N-terminus of erythrocyte band 3 resulted in activation of the src kinase lyn, suggesting that 3-nitroTyr can mimic phosphoTyr in some signalling pathways [311]. Thus the signalling effects of Tyr nitration appear to be complex and pathway-dependent.

\section{Effects of protein cross-linking and aggregation on proteasomal and lysosomal degradation}

In normal cellular conditions oxidised proteins are either repaired, which is limited to a small number of specific modifications such as methionine sulfoxides [312,313], disulfide bonds [314-316] and possibly Tyr nitration (see above), or removed by proteolytic degradation (Figure 7). Cells have highly-regulated intracellular proteolytic systems for the removal of non-functional proteins, such as membrane proteases, lysosomal cathepsins, 
calcium-activated calpains, caspases, mitochondrial proteases and the proteasomal system [317-321]. There is evidence that oxidised proteins, and particularly those containing hydroperoxide groups including Tyr-derived species, can modulate the activity of Cysdependent lysosomal cathepsin enzymes and thereby perturb normal cellular turnover of materials [16]. This inhibition has been shown to involve oxidation of the active site Cys residue by Tyr (and other) hydroperoxides, with inhibition of other structurally-related cathepsins without Cys residues in their active sites being less affected. This may result in a accumulation of damaged materials and consequent toxicity [322,323]. Aggregated/crosslinked materials can undergo autophagocytosis resulting in a major accumulation of the material in lysosomes [324,325].

The major proteolytic system responsible for the removal of oxidised proteins is the proteasome [326-328]. The 20S core proteasome is the main structure of this system, though regulatory units such as 19S (PA700) and 11S (PA28) can attached to the core to give further structures such as the $26 \mathrm{~S}$ proteasome [326,329]. It has been reported that aconitase and other proteins oxidized by peroxynitrite are preferentially degraded by the proteasome [279], and further work has demonstrated that protein Tyr nitration is sufficient to induce accelerated protein degradation [18]. More recently it has been reported that nitration of Tyr46 and Tyr48 in cytochrome c results in cellular degradation [330]. While mildly modified proteins, including limited Tyr nitration, are preferentially degraded, heavily oxidised and cross-linked proteins are poor substrates for the $20 \mathrm{~S}$ proteasome and are able to inhibit proteasome activity. Cross-linked proteins arising from 3,3'-diTyr formation have been investigated in particular [331]. Lipofuscin, ceroid or AGE (advanced glycation end products)-pigment-like fluorophores, insoluble cross-linked materials found at elevated levels within aged cells [322,332,333] may also inhibit this activity. Since the proteasome is a relatively narrow barrel-shaped structure, aggregates may not be capable of being unfolded to enter the central core where the multiple chymotryptic, tryptic and caspase-like active sites are located, leading to poor degradation, accumulation and inhibition of proteasomal activity. Furthermore, aggregate formation is a continuous process and can be accompanied by a time-dependent enlargement of aggregate size.

The $26 \mathrm{~S}$ proteasome is responsible for turnover of most undamaged proteins in an ATP- and ubiquitin ligation-dependent manner, and was assumed not to play a major role in the degradation of oxidized proteins [327]. However, evidence has been presented for inhibition of the tryptic and chymotryptic activity of the $26 \mathrm{~S}$ proteasome by oxidized proteins, at least in part via reaction of hydroperoxides present on proteins, including those present on 
Tyr residues. This inhibition appears to involve oxidation of critical Cys residues on the regulatory subunits [118] and may have significant consequences for the turnover of regulatory proteins and transcription factors, resulting in the potential initiation or continuation of signalling events and the induction of apoptosis [334].

\section{Immunogenicity of Tyr oxidation products}

Post-translational modification of natural amino acids can generate neoepitopes with potential consequences for immunogenicity (reviewed in [335]). The formation of such neoepitopes on autologous proteins can result in antibody formation towards the modified protein, and cross-reactivity of these antibodies towards the unmodified protein, breaking tolerance and potentially triggering an autoimmune response. Several post-translational protein modifications have been associated with autoimmune diseases, including systemic lupus erythematosus (SLE), multiple sclerosis, rheumatoid arthritis and Type 1 diabetes [336,337]. For post-translational modifications of Tyr, only a few reports have been published, such as the demonstration that immunization of B6 mice with modified epidermal growth factor (EGF), in which Tyr29 was mutated to either nitrated or sulfated Tyr, with this resulting in autoantibody formation against native EGF [338]. This clearly shows that Tyr modification can break tolerance against native proteins, and suggests that oxidative modification of Tyr residues may contribute to the etiology of autoimmune disorders. Such cross-reactivity towards non-modified peptide sequences was not observed following the nitration of Tyr97 in cytochrome c [339], indicating that potential autoimmune responses may be sequence- and protein-specific. Immunization of rabbits with nitrated histone H2A resulted in the formation of antibodies, which showed a limited cross-reactivity with native $\mathrm{H} 2 \mathrm{~A}$ [340], and there is evidence for cross-reactivity of antibodies resulting from the immunization of MRL/lpr mice with nitrated IgG towards single-stranded DNA (ssDNA) [341]. Anti-DNA antibodies are a feature of autoimmune diseases such as SLE [342], and it was suggested that the immunogenicity of nitrated autologous proteins such as IgG may trigger anti-DNA antibody formation [342,343]. A robust immune response was also observed after systemic administration of nitrated ovalbumin to mice in a search for a potential role of protein nitration in the induction of food allergies [344]. However, no immune response was detected after oral administration of nitrated ovalbumin, probably due to rapid gastric digestion of the protein. It has also been reported that immunoglobulins have been detected against 3-nitroTyr epitopes in both acute lung injury and coronary artery disease [345,346]. Clearly further studies are needed to document a role of specific Tyr modifications on selected proteins in the 
stimulation of the immune system and in autoimmune disorders. Some results are available on the immunogenicity of brominated proteins, specifically containing 3,5-dibromoTyr [236], but the potential for cross-reactivity with native, non-brominated proteins was not evaluated.

\section{Summary and perspectives}

Tyr oxidation results in the formation of multiple oxidation products, with the nature of the products formed being critically dependent not only on the oxidant, but also on the protein structure and environment. In the majority of cases, oxidation occurs preferentially at the aromatic ring, and in these situations the products are often very similar between the free amino acid and those detected on proteins. Some of these products (e.g. dimers, hydroxylated species) can be formed by multiple processes, whereas others can be diagnostic of particular reactive species. Thus nitrated products indicate the involvement of RNS such as $\mathrm{ONOO}^{-}$and ${ }^{\bullet} \mathrm{NO}_{2}$, while 3-haloTyr are markers for exposure to oxidizing hypohalous acids or $\mathrm{ClO}_{2}{ }^{\bullet}$. 3nitroTyr formation has been widely examined in both aging tissues and diseases, and used as a marker of oxidative stress in human atherosclerosis and diabetes [347-349], hypercholesterolemia in rabbits [350] and aging [351].

A wide range of analytical techniques is available to detect oxidized Tyr, and the appropriate approach depends on whether free Tyr products or protein-bound Tyr are being studied, and the information required. Techniques such as pulse radiolysis and flash photolysis are ideal to study the kinetics of reactions in vitro for free Tyr or small peptides, but are not readily applicable to biological samples. Similarly, data from NMR or EPR analysis is harder to interpret for proteins and complex samples, whereas antibody-based techniques and redox-staining are ideal for visualization of Tyr oxidation products in tissues and proteins. Other methods, such as colorimetric assays and mass spectrometry, can readily be applied to different types of sample, although the sample preparation would vary accordingly.

The development of sensitive and specific techniques is critical to enable study of the mechanisms of formation of Tyr oxidation products and their occurrence in vivo, which may contribute to disease and pathology as there is increasing evidence for their biological effects. Although Tyr oxidation can be repaired and there is evidence that cellular detoxification systems exist, modification of Tyr residues is known to have both structural and functional consequences for the proteins and systems in which they are formed. In many cases, oxidation and nitration interferes with the catalytic mechanism and it can also affect recognition of 
signalling proteins, resulting in disrupted cellular responses. Finally, there is evidence that Tyr oxidation products on proteins are immunogenic, providing a clear link to inflammatory outcomes. The number of biological and biomedical studies on 3-nitroTyr indicates the importance attributed to this modification already, while understanding of other oxidative modifications of Tyr lags behind and represents an important potential target for the future.

\section{Abbreviations}

Apo-AI, apolipoprotein-AI; Apo-B: apolipoprotein B; BSA, bovine serum albumin; CID, collision induced dissociation; Co-fradic, combined fractional diagonal chromatography; DOPA, 3,4-dihydroxyphenylalanine; DTT, dithiothreitol; ECD, electron capture dissociation; ELISA: Enzyme-Linked Immunosorbent Assay; ENDOR: Electron-Nuclear DOuble Resonance; EPR, Electron paramagnetic resonance; ET, electron transfer; FBA: 4formylbenzoylamido tag; FITC: fluorescein isothiocyanate; FTICR, Fourier Transform ion cyclotron resonance; GSH, reduced glutathione; HeLa cells: Henrietta Lacks immortalized cells; HDL, high-density lipoproteins; Huh-7: human hepatoma cell line; iTRAQ: Isobaric tags for relative and absolute quantitation; KLH, Keyhole limpet hemocyanin; LCESI/MS/MS, liquid chromatography coupled to electrospray ionisation tandem mass spectrometry; LRET: long range electron transfer; LTQ-orbitrap: Linear ion Trap Quadrupole mass filter orbitrap; MALDI-TOF MS, matrix assisted laser desorption ionization time of flight mass spectrometry; MnSOD: manganese superoxide dismutase; MPO, myeloperoxidase; oxPTM, oxidative post-translational modification; RONS, reactive oxygen and nitrogen species; RNS, reactive nitrogen species; SERCA: sarco/endoplasmic reticulum $\mathrm{Ca}^{2+}$-ATPase; src kinase: sarcoma Tyr kinase; SPAER: Solid Phase Active Ester Resin; TyrO`, Tyrosine phenoxyl radical (also called tyrosyl radical); RIGhT: reporter ion generation tag.

\section{Acknowledgements}

All authors would like to acknowledge the support of COST Action CM1001. CMS acknowledges financial support from EPSRC for the Proxomics project (EP/I017887/1). 


\section{References}

[1] Aruoma OI, Halliwell B. Molecular biology of free radicals in human diseases. Saint Lucia: OICA International; 1998.

[2] Droge W. Free radicals in the physiological control of cell function. Physiol Rev 2002;82(1):47-95.

[3] Bensasson RV, Land EJ, Truscott TG. Excited states and free radicals in biology and medicine. Oxford: Oxford University Press; 1993.

[4] Bensasson RV, Land EJ, Truscott TG. Pulse Radiolysis and Flash Photolysis: Contributions to the Chemistry of Biology and Medicine. Oxford: Pergamon Press; 1983.

[5] Davies MJ. Reactive species formed on proteins exposed to singlet oxygen. Photochem Photobiol Sci 2004;3(1):17-25.

[6] Sies H. Oxidative stress: from basic research to clinical application. Am J Med 1991;91:31S-38S.

[7] Sies H. Oxidative stress: oxidants and antioxidants. . Exp Physiol 1997;82:291-295.

[8] Forman HJ, Fukuto JM, Torres M. Redox signaling: thiol chemistry defines which reactive oxygen and nitrogen species can act as second messengers. Am J Physiol Cell Physiol 2004;287(2):C246-56.

[9] Kaya A, Lobanov AV, Gerashchenko MV, Koren A, Fomenko DE, Koc A, Gladyshev VN. Thiol Peroxidase Deficiency Leads to Increased Mutational Load and Decreased Fitness in Saccharomyces cerevisiae. Genetics 2014;198(3):905-17.

[10] Spickett CM, Pitt AR. Protein oxidation: role in signalling and detection by mass spectrometry. Amino Acids 2012;42(1):5-21.

[11] Biswas S, Chida AS, Rahman I. Redox modifications of protein-thiols: Emerging roles in cell signaling. Biochem Pharmacol 2006;71(5):551-564.

[12] Heinecke JW. Mechanisms of oxidative damage by myeloperoxidase in atherosclerosis and other inflammatory disorders. J Lab Clin Med 1999;133(4):321325.

[13] Levine RL, Berlett BS, Moskovitz J, Mosoni L, Stadtman ER. Methionine residues may protect proteins from critical oxidative damage. Mech Ageing Dev 1999;107(3):323-332.

[14] Jacob C. Redox signalling via the cellular thiolstat. Biochem Soc Trans 2011;39(5):1247-53.

[15] Kadiiska MB, Gladen BC, Baird DD, Germolec D, Graham LB, Parker CE, Nyska A, Wachsman JT, Ames BN, Basu S and others. Biomarkers of oxidative stress study II. Are oxidation products of lipids, proteins, and DNA markers of $\mathrm{CCl} 4$ poisoning? Free Radic Biol Med 2005;38(6):698-710.

[16] Headlam HA, Gracanin M, Rodgers KJ, Davies MJ. Inhibition of cathepsins and related proteases by amino acid, peptide, and protein hydroperoxides. Free Radic Biol Med 2006;40(9):1539-1548.

[17] Stadtman ER, Levine RL. Free radical-mediated oxidation of free amino acids and amino acid residues in proteins. Amino Acids 2003;25(3-4):207-18.

[18] Souza JM, Choi I, Chen Q, Weisse M, Daikhin E, Yudkoff M, Obin M, Ara J, Horwitz J, Ischiropoulos H. Proteolytic degradation of tyrosine nitrated proteins. Arch Biochem Biophys 2000;380(2):360-6.

[19] Barry BA, Chen J, Keough J, Jenson D, Offenbacher A, Pagba C. Proton-Coupled Electron Transfer and Redox-Active Tyrosines: Structure and Function of the Tyrosyl Radicals in Ribonucleotide Reductase and Photosystem II. J Phys Chem Lett 2012;3(4):543-554. 
[20] Minnihan EC, Nocera DG, Stubbe J. Reversible, long-range radical transfer in E. coli class Ia ribonucleotide reductase. Acc Chem Res 2013;46(11):2524-35.

[21] Stubbe J, van Der Donk WA. Protein Radicals in Enzyme Catalysis. Chem Rev 1998;98(2):705-762.

[22] Solar S, Solar W, Getoff N. Reactivity of OH with Tyrosine in Aqueous-Solution Studied by Pulse-Radiolysis. J Phys Chem A 1984;88(10):2091-2095.

[23] Getoff N. Pulse radiolysis of aromatic amino acids - State of the art. Amino Acids 1992;2(3):195-214.

[24] Chrysochoos J. Pulse radiolysis of phenylalanine and tyrosine. Radiat Res 1968;33(3):465-79.

[25] Lynn KR, Purdie JW. Some Pulse and Gamma-Radiolysis Studies of Tyrosine and Its Glycyl Peptides. Int J Rad Phys Chem 1976;8(6):685-689.

[26] Garrison WM. Reaction-Mechanisms in the Radiolysis of Peptides, Polypeptides, and Proteins. Chem Rev 1987;87(2):381-398.

[27] Cudina I, Josimovic L. The Effect of Oxygen on the Radiolysis of Tyrosine in Aqueous-Solutions. Radiat Res 1987;109(2):206-215.

[28] Hunter EP, Desrosiers MF, Simic MG. The effect of oxygen, antioxidants, and superoxide radical on tyrosine phenoxyl radical dimerization. Free Radic Biol Med 1989;6(6):581-5.

[29] Cohen G, Yakushin S, Dembiec-Cohen D. Protein L-Dopa as an index of hydroxyl radical attack on protein tyrosine. Anal Biochem 1998;263(2):232-239.

[30] Gieseg SP, Simpson JA, Charlton TS, Duncan MW, Dean RT. Protein-Bound 3,4Dihydroxyphenylalanine Is a Major Reductant Formed during Hydroxyl Radical Damage to Proteins. Biochemistry 1993;32(18):4780-4786.

[31] Boguta G, Dancewicz AM. Radiolytic Dimerization of Tyrosine in Alkaline-Solutions of Poly-L-Tyrosine, Glycyl-L-Tyrosine and Tyrosine. Radiat Phys Chem 1982;20(56):359-363.

[32] Boguta G, Dancewicz AM. Radiolytic and Enzymatic Dimerization of Tyrosyl Residues in Insulin, Ribonuclease, Papain and Collagen. Int $\mathrm{J}$ Rad Biol 1983;43(3):249-265.

[33] Hashimoto SK, A.; Imamura, M.; Masuda, T. Lysozyme dimer formation on lysozyme oxidation with $\mathrm{Br} 2$ radical as studied by fluorescence evolution. Int J Radiat Biol Relat Stud Phys Chem Med. 1982;41(3):303-14.

[34] Domazou AS, Koppenol W.H., Gebicki J.M. Efficient repair of protein radicals by ascorbate. Free Radic Biol Med. 2009;46:1049-1057.

[35] Jovanovic SV, Harriman A, Simic MG. Electron-Transfer Reactions of Tryptophan and Tyrosine Derivatives. J Phys Chem A 1986;90(9):1935-1939.

[36] Land EJ, Prutz WA. Reaction of azide radicals with amino acids and proteins. Int J Radiat Biol Relat Stud Phys Chem Med 1979;36(1):75-83.

[37] Ionescu A, Grand D, Sicard-Roselli C, Houee-Levin C. Micellar effect on tyrosine one-electron oxidation by azide radicals. Radiat Phys Chem 2005;72(4):497-506.

[38] Adams GE, Aldrich JE, Bisby RH, Willson RL, Cundall RB, Redpath JL. Selective Free-Radical Reactions with Proteins and Enzymes - Reactions of Inorganic Radical Anions with Amino-Acids. Radiat Res 1972;49(2):278-289.

[39] Napolitano MJ, Green BJ, Nicoson JS, Margerum DW. Chlorine dioxide oxidations of tyrosine, N-acetyltyrosine, and dopa. Chem Res Toxicol 2005;18(3):501-8.

[40] Curtis MP, Hicks AJ, Neidigh JW. Kinetics of 3-Chlorotyrosine Formation and Loss due to Hypochlorous Acid and Chloramines. Chem Res Toxicol 2011;24(3):418-428.

[41] Alfassi ZB. Selective Oxidation of Tyrosine Oxidation by $\mathrm{NO}_{2}$ and $\mathrm{ClO}_{2}$ at Basic Ph. Radiat Phys Chem 1987;29(5):405-406. 
[42] Sharma V, Sohn M. Reactivity of chlorine dioxide with amino acids, peptides, and proteins. Environmental Chem Lett 2012;10(3):255-264.

[43] Pattison DI, Davies MJ. Absolute rate constants for the reaction of hypochlorous acid with protein side chains and peptide bonds. Chem Res Toxicol 2001;14(10):1453-64.

[44] Navalon S, Alvaro M, Garcia H. Chlorine dioxide reaction with selected amino acids in water. J Hazard Mater 2009;164(2-3):1089-97.

[45] Ogata N. Denaturation of protein by chlorine dioxide: oxidative modification of tryptophan and tyrosine residues. Biochemistry 2007;46(16):4898-911.

[46] Augusto O, Bonini MG, Amanso AM, Linares E, Santos CCX, De Menezes SL. Nitrogen dioxide and carbonate radical anion: Two emerging radicals in biology. Free Radic Biol Med 2002;32(9):841-859.

[47] Prütz WA. Tyrosine Oxidation by $\mathrm{NO}_{2}$ In Aqueous-Solution. $\mathrm{Z}$ Naturforsch $\mathrm{C}$ 1984;39(7-8):725-727.

[48] Clarke K, Edge R, Johnson V, Land EJ, Navaratnam S, Truscott TG. Direct observation of $\mathrm{NH}_{2} *$ reactions with oxygen, amino acids, and melanins. J Phys Chem A 2008;112(6):1234-7.

[49] Alvarez B, Ferrer-Sueta G, Freeman BA, Radi R. Kinetics of peroxynitrite reaction with amino acids and human serum albumin. J Biol Chem 1999;274(2):842-848.

[50] Alvarez B, Radi R. Peroxynitrite reactivity with amino acids and proteins. Amino Acids 2003;25(3-4):295-311.

[51] Gunaydin H, Houk KN. Mechanisms of peroxynitrite-mediated nitration of tyrosine. Chem Res Toxicol 2009;22(5):894-8.

[52] Ferrer-Sueta G, Radi R. Chemical biology of peroxynitrite: kinetics, diffusion, and radicals. ACS Chem Biol 2009;4(3):161-77.

[53] Goldstein S, Czapski G, Lind J, Merenyi G. Tyrosine nitration by simultaneous generation of (.)NO and O-(2) under physiological conditions. How the radicals do the job. J Biol Chem 2000;275(5):3031-6.

[54] Goldstein S, Lind J, Merenyi G. Chemistry of peroxynitrites as compared to peroxynitrates. Chem Rev 2005;105(6):2457-2470.

[55] Lymar SV, Jiang Q, Hurst JK. Mechanism of carbon dioxide-catalyzed oxidation of tyrosine by peroxynitrite. Biochemistry 1996;35(24):7855-61.

[56] Zhang H, Joseph J, Feix J, Hogg N, Kalyanaraman B. Nitration and oxidation of a hydrophobic tyrosine probe by peroxynitrite in membranes: comparison with nitration and oxidation of tyrosine by peroxynitrite in aqueous solution. Biochemistry 2001;40(25):7675-86.

[57] Kapoor SK, Gopinathan C. Reactions of Halogenated Organic Peroxyl Radicals with Various Purine Derivatives, Tyrosine, and Thymine - a Pulse-Radiolysis Study. Int J Chem Kinetics 1992;24(12):1035-1042.

[58] Bartesaghi S, Wenzel J, Trujillo M, Lopez M, Joseph J, Kalyanaraman B, Radi R. Lipid Peroxyl Radicals Mediate Tyrosine Dimerization and Nitration in Membranes. Chem Res Toxicol 2010;23(4):821-835.

[59] Folkes LK, Bartesaghi S, Trujillo M, Radi R, Wardman P. Kinetics of oxidation of tyrosine by a model alkoxyl radical. Free Radic Res 2012;46(9):1150-6.

[60] Lind J, Shen X, Eriksen TE, Merenyi G. The One-Electron Reduction Potential of 4Substituted Phenoxyl Radicals in Water. J Am Chem Soc 1990;112(2):479-482.

[61] Davies MJ. Identification of a globin free radical in equine myoglobin treated with peroxides. Biochim Biophys Acta 1991;1077(1):86-90.

[62] Pattison DI, Rahmanto AS, Davies MJ. Photo-oxidation of proteins. Photochem Photobiol Sci 2012;11(1):38-53. 
[63] Davies MJ. Singlet oxygen-mediated damage to proteins and its consequences. Biochem Biophys Res Commun 2003;305(3):761-70.

[64] Straight RC, Spikes JD. Singlet $\mathrm{O}_{2}$. Frimer AA, editor. Boca Raton, USA: CRC Press; 1985.

[65] Wilkinson F, Helman, W. P., Ross, A. B. . Rate Constants for the Decay and Reactions of the Lowest Electronically Excited Singlet-State of Molecular Oxygen in Solution - an Expanded and Revised Compilation. J. Phys. Chem. Ref. Data 1995;24:663-1021.

[66] Criado S, Soltermann AT, Marioli JM, Garcia NA. Sensitized photooxidation of diand tripeptides of tyrosine. Photochemistry and Photobiology 1998;68(4):453-458.

[67] Jin FM, Leitich J, von Sonntag C. The Superoxide Radical Reacts with TyrosineDerived Phenoxyl Radicals by Addition Rather Than by Electron-Transfer. J Chem Soc, Perkin Trans 1 1993(9):1583-1588.

[68] Wright A, Bubb WA, Hawkins CL, Davies MJ. Singlet oxygen-mediated protein oxidation: evidence for the formation of reactive side chain peroxides on tyrosine residues. Photochem Photobiol 2002;76(1):35-46.

[69] Katsuya E, Seya, K., Hikino, H. Photo-oxidation of L-tyrosine, an efficient, 1,4chirality transfer reaction. J Chem Soc Chem Commun 1998:934-935.

[70] Wright A, Hawkins CL, Davies MJ. Singlet oxygen-mediated protein oxidation: evidence for the formation of reactive peroxides. Redox Rep 2000;5(2-3):159-61.

[71] Pedersen JZ, Finazzi-Agro A. Protein-radical enzymes. FEBS Lett 1993;325(1-2):538.

[72] Stubbe J, Riggs-Gelasco P. Harnessing free radicals: formation and function of the tyrosyl radical in ribonucleotide reductase. Trends Biochem Sci 1998;23(11):438-443.

[73] Miller YI, Shaklai N. Oxidative crosslinking of LDL protein induced by hemin: involvement of tyrosines. Biochem Mol Biol Int 1994;34(6):1121-9.

[74] Miki Y, Pogni R, Acebes S, Lucas F, Fernandez-Fueyo E, Baratto MC, Fernandez MI, de los Rios V, Ruiz-Duenas FJ, Sinicropi A and others. Formation of a tyrosine adduct involved in lignin degradation by Trametopsis cervina lignin peroxidase: a novel peroxidase activation mechanism. Biochem J 2013;452(3):575-84.

[75] Heinecke JW, Li W, Daehnke HL, Goldstein JA. Dityrosine, a Specific Marker of Oxidation, Is Synthesized by the Myeloperoxidase-Hydrogen Peroxide System of Human Neutrophils and Macrophages. J Biol Chem 1993;268(6):4069-4077.

[76] Foerder CA, Shapiro BM. Release of ovoperoxidase from sea urchin eggs hardens the fertilization membrane with tyrosine crosslinks. Proc Natl Acad Sci U S A 1977;74(10):4214-8.

[77] Burzio LA, Waite JH. Reactivity of peptidyl-tyrosine to hydroxylation and crosslinking. Protein Science 2001;10(4):735-740.

[78] Mai K, Smith NC, Feng ZP, Katrib M, Slapeta J, Slapetova I, Wallach MG, Luxford $\mathrm{C}$, Davies MJ, Zhang $\mathrm{X}$ and others. Peroxidase catalysed cross-linking of an intrinsically unstructured protein via dityrosine bonds in the oocyst wall of the apicomplexan parasite, Eimeria maxima. Int J Parasitol 2011;41(11):1157-64.

[79] Cheng G, Li H, Cao Z, Qiu X, McCormick S, Thannickal VJ, Nauseef WM. Vascular peroxidase-1 is rapidly secreted, circulates in plasma, and supports dityrosine crosslinking reactions. Free Radic Biol Med 2011;51(7):1445-53.

[80] Nagano S, Huang X, Moir RD, Payton SM, Tanzi RE, Bush AI. Peroxidase activity of cyclooxygenase-2 (COX-2) cross-links beta-amyloid (Abeta) and generates AbetaCOX-2 hetero-oligomers that are increased in Alzheimer's disease. J Biol Chem 2004;279(15):14673-8. 
[81] Abello N, Kerstjens HA, Postma DS, Bischoff R. Protein tyrosine nitration: selectivity, physicochemical and biological consequences, denitration, and proteomics methods for the identification of tyrosine-nitrated proteins. J Proteome Res 2009;8(7):3222-38.

[82] Astier J, Kulik A, Koen E, Besson-Bard A, Bourque S, Jeandroz S, Lamotte O, Wendehenne D. Protein S-nitrosylation: What's going on in plants? Free Radic Biol Med 2012;53(5):1101-1110.

[83] Tien M, Berlett BS, Levine RL, Chock PB, Stadtman ER. Peroxynitrite-mediated modification of proteins at physiological carbon dioxide concentration: $\mathrm{pH}$ dependence of carbonyl formation, tyrosine nitration, and methionine oxidation. Proc Natl Acad Sci U S A. 1999;96(14):7809-7814.

[84] van der Vliet A, Eiserich JP, Halliwell B, Cross CE. Formation of reactive nitrogen species during peroxidase-catalyzed oxidation of nitrite. A potential additional mechanism of nitric oxide-dependent toxicity. J Biol Chem 1997;272(12):7617-25.

[85] Gao P, Song Y, Li H, Gao Z. Efficiency of methemoglobin, hemin and ferric citrate in catalyzing protein tyrosine nitration, protein oxidation and lipid peroxidation in a bovine serum albumin-liposome system: influence of $\mathrm{pH}$. J Inorg Biochem 2009;103(5):783-90.

[86] Kambayashi Y, Hitomi Y, Kodama N, Kubo M, Okuda J, Takemoto K, Shibamori M, Takigawa T, Ogino K. pH profile of cytochrome c-catalyzed tyrosine nitration. Acta Biochim Pol 2006;53(3):577-84.

[87] Castro L, Eiserich JP, Sweeney S, Radi R, Freeman BA. Cytochrome c: a catalyst and target of nitrite-hydrogen peroxide-dependent protein nitration. Arch Biochem Biophys 2004;421(1):99-107.

[88] Nicolis S, Monzani E, Roncone R, Gianelli L, Casella L. Metmyoglobin-catalyzed exogenous and endogenous tyrosine nitration by nitrite and hydrogen peroxide. Chemistry 2004;10(9):2281-90.

[89] Chavarria C, Souza JM. Oxidation and nitration of alpha-synuclein and their implications in neurodegenerative diseases. Arch Biochem Biophys 2013;533(1-2):2532.

[90] Vlasova, II, Sokolov AV, Arnhold J. The free amino acid tyrosine enhances the chlorinating activity of human myeloperoxidase. J Inorg Biochem 2012;106(1):76-83.

[91] Kurita N, Mise N, Fujii A, Mori M, Sai K, Nishi T, Suzuki T, Tagawa H, Sugimoto T. Myeloperoxidase-antineutrophil cytoplasmic antibody-associated crescentic glomerulonephritis with rheumatoid arthritis: a comparison of patients without rheumatoid arthritis. Clin Exp Nephrol 2010;14(4):325-32.

[92] Son TG, Zou Y, Yu BP, Lee J, Chung HY. Aging effect on myeloperoxidase in rat kidney and its modulation by calorie restriction. Free Radic Res 2005;39(3):283-289.

[93] Baldus S, Eiserich JP, Brennan ML, Jackson RM, Alexander CB, Freeman BA. Spatial mapping of pulmonary and vascular nitrotyrosine reveals the pivotal role of myeloperoxidase as a catalyst for tyrosine nitration in inflammatory diseases. Free Radic Biol Med 2002;33(7):1010.

[94] Irwin JA, Ostdal H, Davies MJ. Myoglobin-induced oxidative damage: Evidence for radical transfer from oxidized myoglobin to other proteins and antioxidants. Arch Biochem Biophys 1999;362(1):94-104.

[95] Ostdal H, Skibsted LH, Andersen HJ. Formation of long-lived protein radicals in the reaction between $\mathrm{H} 2 \mathrm{O} 2$-activated metmyoglobin and other proteins. Free Radic Biol Med 1997;23(5):754-761.

[96] Ostdal H, Davies MJ, Andersen HJ. Reaction between protein radicals and other biomolecules. Free Radic Biol Med 2002;33(2):201-209. 
[97] DiMarco C, Giulivi C. Current analytical methods for the detection of dityrosine, a biomarker of oxidative stress, in biological samples. Mass Spectrom Rev 2007;26:108-120.

[98] Eiserich JP, Butler J, van der Vliet A, Cross CE, Halliwell B. Nitric oxide rapidly scavenges tyrosine and tryptophan radicals. Biochem J 1995;310 ( Pt 3):745-9.

[99] Goodwin DC, Gunther MR, Hsi LC, Crews BC, Eling TE, Mason RP, Marnett LJ. Nitric oxide trapping of tyrosyl radicals generated during prostaglandin endoperoxide synthase turnover. Detection of the radical derivative of tyrosine 385. J Biol Chem 1998;273(15):8903-9.

[100] Prütz WA, Mönig H, Butler J, Land EJ. Reactions of nitrogen dioxide in aqueous model systems: oxidation of tyrosine units in peptides and proteins. Arch Biochem Biophys 1985;243(1):125-34.

[101] Kikugawa K, Kato T, Okamoto Y. Damage of Amino-Acids and Proteins Induced by Nitrogen-Dioxide, a Free-Radical Toxin, in Air. Free Radic Biol Med 1994;16(3):373382.

[102] Greenacre SAB, Ischiropoulos H. Tyrosine nitration: Localisation, quantification, consequences for protein function and signal transduction. Free Radic Res 2001;34(6):541-581.

[103] Ischiropoulos H. Protein tyrosine nitration-An update. Arch Biochem Biophys 2009;484(2):117-121.

[104] Radi R. Nitric oxide, oxidants, and protein tyrosine nitration. Proc Natl Acad Sci U S A 2004;101(12):4003-8.

[105] Lepoivre M, Houee-Levin C, Coeytaux K, Decottignies P, Auger G, Lemaire G. Nitration of the tyrosyl radical in ribonucleotide reductase by nitrogen dioxide: a gamma radiolysis study. Free Radic Biol Med 2005;38(11):1511-7.

[106] Winterbourn CC, Parsons-Mair HN, Gebicki S, Gebicki JM, Davies MJ. Requirements for superoxide-dependent tyrosine hydroperoxide formation in peptides. Biochem J 2004;381(Pt 1):241-8.

[107] Winterbourn CC, Pichorner H, Kettle AJ. Myeloperoxidase-dependent generation of a tyrosine peroxide by neutrophils. Arch Biochem Biophys 1997;338(1):15-21.

[108] Prütz WA, Butler J, Land EJ. Phenol coupling initiated by one-electron oxidation of tyrosine units in peptides and histone. Int J Radiat Biol Relat Stud Phys Chem Med 1983;44(2):183-96.

[109] d'Alessandro N, Bianchi G, Fang XW, Jin FM, Schuchmann HP, von Sonntag C. Reaction of superoxide with phenoxyl-type radicals. Perkin Trans 2 2000(9):18621867.

[110] Das AB, Nagy P, Abbott HF, Winterbourn CC, Kettle AJ. Reactions of superoxide with the myoglobin tyrosyl radical. Free Radic Biol Med 2010;48(11):1540-1547.

[111] Nagy P, Kettle AJ, Winterbourn CC. Superoxide-mediated Formation of Tyrosine Hydroperoxides and Methionine Sulfoxide in Peptides through Radical Addition and Intramolecular Oxygen Transfer. J Biol Chem 2009;284(22):14723-14733.

[112] Jin F, Leitich, J and von Sonntag, C. . The superoxide radical reacts with tyrosinederived phenoxyl radicals by addition rather than by electron transfer. . J Chem Soc Perkin Trans 2 1993:1583-1588.

[113] D'Alessandro N, Bianchi, G, Fang, X, Jin, F, Schuchmann, H-P and von Sonntag, C. . Reaction of superoxide with phenoxyl-type radicals. . J Chem Soc Perkin Trans 2 2000:1862-1867.

[114] Mozziconacci O, Mirkowski J, Rusconi F, Pernot P, Bobrowski K, Houee-Levin C. Superoxide radical anions protect enkephalin from oxidation if the amine group is blocked. Free Radic Biol Med 2007;43(2):229-240. 
[115] Shchepin R, Moller MN, Kim HY, Hatch DM, Bartesaghi S, Kalyanaraman B, Radi $\mathrm{R}$, Porter NA. Tyrosine-lipid peroxide adducts from radical termination: para coupling and intramolecular Diels-Alder cyclization. J Am Chem Soc 2010;132(49):17490-500.

[116] Saeed S, Gillies D, Wagner G, Howell NK. ESR and NMR spectroscopy studies on protein oxidation and formation of dityrosine in emulsions containing oxidised methyl linoleate. Food Chem Toxicol 2006;44(8):1385-92.

[117] Gracanin M, Davies MJ. Inhibition of protein tyrosine phosphatases by amino acid, peptide, and protein hydroperoxides: potential modulation of cell signaling by protein oxidation products. Free Radic Biol Med 2007;42(10):1543-51.

[118] Gracanin M, Lam MA, Morgan PE, Rodgers KJ, Hawkins CL, Davies MJ. Amino acid, peptide, and protein hydroperoxides and their decomposition products modify the activity of the 26S proteasome. Free Radic Biol Med 2011;50(2):389-399.

[119] Dremina ES, Sharov VS, Davies MJ, Schoneich C. Oxidation and inactivation of SERCA by selective reaction of cysteine residues with amino acid peroxides. Chem Res Toxicol 2007;20(10):1462-9.

[120] Nagy P, Kettle AJ, Winterbourn CC. Neutrophil-mediated oxidation of enkephalins via myeloperoxidase-dependent addition of superoxide. Free Radic Biol Med 2010;49(5):792-9.

[121] Prütz WA. Free-Radical Transfer Involving Sulfur Peptide Functions. Sulfur-Centered Reactive Intermediates in Chemistry and Biology 1990;197:389-399.

[122] Zhang H, Xu YK, Joseph J, Kalyanaraman B. Intramolecular electron transfer between tyrosyl radical and cysteine residue inhibits tyrosine nitration and induces thiyl radical formation in model peptides treated with myeloperoxidase, $\mathrm{H} 2 \mathrm{O} 2$, and NO2- - EPR spin trapping studies. J Biol Chem 2005;280(49):40684-40698.

[123] Prütz WA, Butler J, Land EJ, Swallow AJ. Unpaired electron migration between aromatic and sulfur peptide units. Free Radic Res Commun 1986;2(1-2):69-75.

[124] Ito N, Phillips SEV, Stevens C, Ogel ZB, Mcpherson MJ, Keen JN, Yadav KDS, Knowles PF. Novel Thioether Bond Revealed by a 1.7-a Crystal-Structure of Galactose-Oxidase. Nature 1991;350(6313):87-90.

[125] Ye S, Wu X, Wei L, Tang DM, Sun P, Bartlam M, Rao ZH. An insight into the mechanism of human cysteine dioxygenase - Key roles of the thioether-bonded tyrosine-cysteine cofactor. J Biol Chem 2007;282(5):3391-3402.

[126] Lee Y, Lee DH, Sarjeant AA, Karlin KD. Thiol-copper(I) and disulfide-dicopper(I) complex O2-reactivity leading to sulfonate-copper(II) complex or the formation of a cross-linked thioether-phenol product with phenol addition. J Inorg Biochem 2007;101(11-12):1845-58.

[127] Rogers MS, Hurtado-Guerrero R, Firbank SJ, Halcrow MA, Dooley DM, Phillips SE, Knowles PF, McPherson MJ. Cross-link formation of the cysteine 228-tyrosine 272 catalytic cofactor of galactose oxidase does not require dioxygen. Biochemistry 2008;47(39):10428-39.

[128] Nauser T, Casi G, Koppenol WH, Schoneich C. Intramolecular addition of cysteine thiyl radicals to phenylalanine in peptides: formation of cyclohexadienyl type radicals. Chem Commun (Camb) 2005(27):3400-2.

[129] Firbank SJ, Rogers MS, Wilmot CM, Dooley DM, Halcrow MA, Knowles PF, McPherson MJ, Phillips SE. Crystal structure of the precursor of galactose oxidase: an unusual self-processing enzyme. Proc Natl Acad Sci U S A 2001;98(23):12932-7.

[130] Davies MJ. Myeloperoxidase-derived oxidation: mechanisms of biological damage and its prevention. J Clin Biochem Nutr 2011;48(1):8-19. 
[131] Davies MJ, Hawkins CL, Pattison DI, Rees MD. Mammalian heme peroxidases: from molecular mechanisms to health implications. Antioxid Redox Signal 2008;10(7):1199-234.

[132] Pattison DI, Davies MJ. Reactions of myeloperoxidase-derived oxidants with biological substrates: Gaining chemical insight into human inflammatory diseases. Curr Med Chem 2006;13(27):3271-3290.

[133] Pattison DI, Davies MJ. Kinetic analysis of the reactions of hypobromous acid with protein components: implications for cellular damage and use of 3-bromotyrosine as a marker of oxidative stress. Biochemistry 2004;43(16):4799-809.

[134] Domigan NM, Charlton T.S., Duncan M.W., Winterbourn C.C., Kettle A.J. Chlorination of tyrosyl residues in peptides by myeloperoxidase and human neutrophils. J Biol Chem 1995;270:16542-16548.

[135] Henderson JP, Byun J, Williams MV, Mueller DM, McCormick ML, Heinecke JW. Production of brominating intermediates by myeloperoxidase - A transhalogenation pathway for generating mutagenic nucleobases during inflammation. J Biol Chem 2001;276(11):7867-7875.

[136] Foote CS, Goyne TE, Lehrer RI. Assessment of chlorination by human neutrophils. Nature 1983;301(5902):715-6.

[137] Kettle AJ. Neutrophils convert tyrosyl residues in albumin to chlorotyrosine. Febs Letters 1996;379(1):103-106.

[138] Wu W, Chen Y, d'Avignon A, Hazen SL. 3-Bromotyrosine and 3,5-dibromotyrosine are major products of protein oxidation by eosinophil peroxidase: potential markers for eosinophil-dependent tissue injury in vivo. Biochemistry 1999;38(12):3538-48.

[139] Hazen SL, Hsu FF, Heinecke JW. p-hydroxyphenylacetaldehyde is the major product of L-tyrosine oxidation by activated human phagocytes - A chloride-dependent mechanism for the conversion of free amino acids into reactive aldehydes by myeloperoxidase. J Biol Chem 1996;271(4):1861-1867.

[140] Aune TM, Thomas EL, Morrison M. Lactoperoxidase-Catalyzed Incorporation of Thiocyanate Ion into a Protein Substrate. Biochemistry 1977;16(21):4611-4615.

[141] Hazen SL, Gaut JP, Crowley JR, Hsu FF, Heinecke JW. Elevated levels of proteinbound p-hydroxyphenylacetaldehyde, an amino-acid-derived aldehyde generated by myeloperoxidase, are present in human fatty streaks, intermediate lesions and advanced atherosclerotic lesions. Biochem J 2000;352:693-699.

[142] Hazen SL, Hsu FF, d'Avignon A, Heinecke JW. Human neutrophils employ myeloperoxidase to convert alpha-amino acids to a battery of reactive aldehydes: A pathway for aldehyde generation at sites of inflammation. Biochemistry 1998;37(19):6864-6873.

[143] Fu S, Wang H, Davies M, Dean R. Reactions of hypochlorous acid with tyrosine and peptidyl-tyrosyl residues give dichlorinated and aldehydic products in addition to 3chlorotyrosine. J Biol Chem 2000;275(15):10851-8.

[144] Bobrowski K. Electron migration in peptides and proteins. In: Mayer J, editor. Properties and reactions of radiation induced transients. Selected topics Warszawa Poland: Polish Scientific Publishers PWN; 1999.

[145] Bobrowski K. Radiation-induced radical reactions. In: Chatgilialoglu C, Studer, A., editor. Encyclopedia of Radicals in Chemistry, Biology and Materials. Volume 1. New York USA: John Wiley \& Sons Ltd; 2012.

[146] Zhang H, Zielonka J, Sikora A, Joseph J, Xu Y, Kalyanaraman B. The effect of neighboring methionine residue on tyrosine nitration and oxidation in peptides treated with MPO, H2O2, and NO2(-) or peroxynitrite and bicarbonate: role of intramolecular electron transfer mechanism? Arch Biochem Biophys 2009;484(2):134-45. 
[147] DeFelippis MR, Murthy CP, Faraggi M, Klapper MH. Pulse Radiolytic Measurement of Redox Potentials - the Tyrosine and Tryptophan Radicals. Biochemistry 1989;28(11):4847-4853.

[148] Harriman A. Further Comments on the Redox Potentials of Tryptophan and Tyrosine. J Phys Chem A 1987;91(24):6102-6104.

[149] DeFelippis MR, Murthy CP, Broitman F, Weinraub D, Faraggi M, Klapper MH. Electrochemical Properties of Tyrosine Phenoxy and Tryptophan Indolyl Radicals in Peptides and Amino-Acid-Analogs. J Phys Chem A 1991;95(8):3416-3419.

[150] Song QH, Guo QX, Yao SD, Lin NY. Comparison of intermediates of tryptophan, tyrosine and their dipeptide induced by $\mathrm{UV}$ light and $\mathrm{SO}_{4}{ }^{\circ}$. Res Chem Intermediat 2002;28(4):329-335.

[151] Tanner C, Navaratnam S, Parsons BJ. Intramolecular electron transfer in the dipeptide, histidyltyrosine: a pulse radiolysis study. Free Radic Biol Med 1998;24(4):671-8.

[152] Morozova OB, Yurkovskaya AV. Intramolecular electron transfer in the photooxidized peptides tyrosine-histidine and histidine-tyrosine: a time-resolved CIDNP study. Angew Chem Int Ed Engl 2010;49(43):7996-9.

[153] Bobrowski K, Wierzchowski KL, Holcman J, Ciurak M. Intramolecular ElectronTransfer in Peptides Containing Methionine, Tryptophan and Tyrosine - a PulseRadiolysis Study. Int J Rad Biol 1990;57(5):919-932.

[154] Bobrowski K, Wierzchowski KL, Holcman J, Ciurak M. Pulse-Radiolysis Studies of Intramolecular Electron-Transfer in Model Peptides and Proteins .4. Met/S-Br-]Tyr/O Radical Transformation in Aqueous-Solution of H-Tyr-(Pro)N-Met-Oh Peptides. Int J Rad Biol 1992;62(5):507-516.

[155] Marcus RA, Sutin N. Electron transfers in chemistry and biology. Biochim Biophys Acta 1985;811(3):265-322.

[156] Gray HB, Winkler JR. Long-range electron transfer. Proc Natl Acad Sci U S A 2005;102(10):3534-9.

[157] Barry BA, Einarsdottir O. Insights into the structure and function of redox-active tyrosines from model compounds. J Phys Chem B 2005;109(15):6972-6981.

[158] Giese B, Wang M, Gao J, Stoltz M, Muller P, Graber M. Electron relay race in peptides. J Org Chem 2009;74(10):3621-5.

[159] Hoganson CW, Tommos C. The function and characteristics of tyrosyl radical cofactors. Biochim Biophys Acta 2004;1655(1-3):116-122.

[160] Smith WL, Eling TE, Kulmacz RJ, Marnett LJ, Tsai AL. Tyrosyl Radicals and Their Role in Hydroperoxide-Dependent Activation and Inactivation of Prostaglandin Endoperoxide Synthase. Biochemistry 1992;31(1):3-7.

[161] Whittaker MM, Whittaker JW. A tyrosine-derived free radical in apogalactose oxidase. J Biol Chem 1990;265(17):9610-3.

[162] Ostermeier C, Harrenga A, Ermler U, Michel H. Structure at 2.7 A resolution of the Paracoccus denitrificans two-subunit cytochrome c oxidase complexed with an antibody FVâ€\%ofragment. Proc Natl Acad Sci U S A. 1997;94(20):10547-10553.

[163] Stubbe J, Nocera DG, Yee CS, Chang MCY. Radical initiation in the class I ribonucleotide reductase: Long-range proton-coupled electron transfer? Chem Rev 2003;103(6):2167-2201.

[164] Barry BA, Babcock GT. Tyrosine Radicals Are Involved in the Photosynthetic Oxygen-Evolving System. Proc Natl Acad Sci U S A. 1987;84(20):7099-7103.

[165] Aubert C, Mathis P, Eker APM, Brettel K. Intraprotein electron transfer between tyrosine and tryptophan in DNA photolyase from Anacystis nidulans. Proc Natl Acad Sci U S A. 1999;96(10):5423-5427. 
[166] Lee CY. A possible biological role of the electron transfer between tyrosine and tryptophan. Gating of ion channels. FEBS Lett 1992;299(2):119-23.

[167] Nugent JH, Ball RJ, Evans MC. Photosynthetic water oxidation: the role of tyrosine radicals. Biochim Biophys Acta 2004;1655(1-3):217-21.

[168] Szczepaniak M, Sugiura M, Holzwarth AR. The role of TyrD in the electron transfer kinetics in Photosystem II. Biochim Biophys Acta 2008;1777(12):1510-7.

[169] Boerner RJ, Bixby KA, Nguyen AP, Noren GH, Debus RJ, Barry BA. Removal of Stable Tyrosine Radical D+ Affects the Structure or Redox Properties of Tyrosine-Z in Manganese-Depleted Photosystem-Ii Particles from Synechocystis 6803. J Biol Chem 1993;268(3):1817-1823.

[170] Faller P, Goussias C, Rutherford AW, Un S. Resolving intermediates in biological proton-coupled electron transfer: a tyrosyl radical prior to proton movement. Proc Natl Acad Sci U S A 2003;100(15):8732-5.

[171] Pujols-Ayala I, Sacksteder CA, Barry BA. Redox-active tyrosine residues: role for the peptide bond in electron transfer. J Am Chem Soc 2003;125(25):7536-8.

[172] Pujols-Ayala I, Barry BA. Tyrosyl radicals in photosystem II. Biochim Biophys Acta 2004;1655(1-3):205-16.

[173] Martinez A, Peluffo G, Petruk AA, Hugo M, Pineyro D, Demicheli V, Moreno DM, Lima A, Batthyany C, Duran R and others. Structural and molecular basis of the peroxynitrite-mediated nitration and inactivation of Trypanosoma cruzi ironsuperoxide dismutases (Fe-SODs) A and B: disparate susceptibilities due to the repair of Tyr35 radical by Cys 83 in Fe-SODB through intramolecular electron transfer. J Biol Chem 2014;289(18):12760-78.

[174] Petruk AA, Bartesaghi S, Trujillo M, Estrin DA, Murgida D, Kalyanaraman B, Marti MA, Radi R. Molecular basis of intramolecular electron transfer in proteins during radical-mediated oxidations: computer simulation studies in model tyrosine-cysteine peptides in solution. Arch Biochem Biophys 2012;525(1):82-91.

[175] Wang M, Gao J, Muller P, Giese B. Electron Transfer in Peptides with Cysteine and Methionine as Relay Amino Acids. Angew Chem Int Ed Engl 2009;48(23):42324234.

[176] Cordes M, Kottgen A, Jasper C, Jacques O, Boudebous H, Giese B. Influence of amino acid side chains on long-distance electron transfer in peptides: Electron hopping via "Stepping Stones". Angew Chem Int Ed Engl 2008;47(18):3461-3463.

[177] Gao J, Muller P, Wang M, Eckhardt S, Lauz M, Fromm KM, Giese B. Electron transfer in peptides: the influence of charged amino acids. Angew Chem Int Ed Engl 2011;50(8):1926-30.

[178] Houee-Levin C, Bobrowski K. The use of the methods of radiolysis to explore the mechanisms of free radical modifications in proteins. J Proteomics 2013;92:51-62.

[179] Roffi G. In: Baxendale JH, Busi, F., editor. The Study of Fast Processes and Transient Species by Electron Pulse Radiolysis. Dordrecht: Reidel Publishing Company; 1982.

[180] Janata E. Pulse-Radiolysis Conductivity Measurements in Aqueous-Solutions with Nanosecond Time Resolution. Radiat Phys Chem 1982;19(1):17-21.

[181] Madden KP, McManus, H. J. D., Fessenden, R. W. . Rev. Sci. Instrum. 1994;65:49.

[182] Tripathi GNR. In: Clark RHJ, Hester, R. E., editor. Time-resolved Spectroscopy. Volume 18. New York (USA): John Wiley \& Sons; 1989.

[183] Warman J. In: Baxendale JH, Busi, F., editor. The Study of Fast Processes and Transient Species by Electron Pulse Radiolysis. Dordrecht: D. Reidel Publishing Company; 1982.

[184] Warman JM, De Haas, M. P. In: Wishart JF, Rao, B. S. M., editor. Recent Trends in Radiation Chemistry. Singapore: World Scientific; 2010. 
[185] Connor DB. Pulse radiolysis with circular dichroism detection. Radiat Phys Chem 1994;44:371-376.

[186] Le Caer S, Pin, S.,Renault, J. P.,Vigneron, G, Pommeret, S. In: Wishart JF, Rao, B. S. M., editor. Recent Trends in Radiation Chemistry. Singapore: World Scientific; 2010.

[187] Klug CA, Burzio LA, Waite JH, Schaefer J. In situ analysis of peptidyl DOPA in mussel byssus using rotational-echo double-resonance NMR. Arch Biochem Biophys 1996;333(1):221-224.

[188] Ozawa K, Headlam MJ, Mouradov D, Watt SJ, Beck JL, Rodgers KJ, Dean RT, Huber T, Otting G, Dixon NE. Translational incorporation of L-3,4dihydroxyphenylalanine into proteins. Febs Journal 2005;272(12):3162-3171.

[189] Tommos C, Davidsson L, Svensson B, Madsen C, Vermaas W, Styring S. Modified EPR spectra of the tyrosineD radical in photosystem II in site-directed mutants of Synechocystis sp. PCC 6803: identification of side chains in the immediate vicinity of tyrosineD on the D2 protein. Biochemistry 1993;32(20):5436-41.

[190] Sealy RC, Harman L, West PR, Mason RP. The electron spin resonance spectrum of the tyrosyl radical. J Am Chem Soc 1985;107(12):3401-3406.

[191] Hoganson CW, Babcock GT. Protein Tyrosyl Radical Interactions in Photosystem-Ii Studied by Electron-Spin-Resonance and Electron Nuclear Double-Resonance Spectroscopy - Comparison with Ribonucleotide Reductase and Invitro Tyrosine. Biochemistry 1992;31(47):11874-11880.

[192] Gunther MR, Sturgeon BE, Mason RP. A long-lived tyrosyl radical from the reaction between horse metmyoglobin and hydrogen peroxide. Free Radic Biol Med 2000;28(5):709-719.

[193] Davies MJ. Detection of myoglobin-derived radicals on reaction of metmyoglobin with hydrogen peroxide and other peroxidic compounds. Free Radic Res Commun 1990;10(6):361-70.

[194] Svistunenko DA, Dunne J, Fryer M, Nicholls P, Reeder BJ, Wilson MT, Bigotti MG, Cutruzzola F, Cooper CE. Comparative study of tyrosine radicals in hemoglobin and myoglobins treated with hydrogen peroxide. Biophys J 2002;83(5):2845-55.

[195] McArthur KM, Davies MJ. Detection and reactions of the globin radical in haemoglobin. Biochim Biophys Acta 1993;1202(2):173-81.

[196] Davies MJ, Puppo A. Direct detection of a globin-derived radical in leghaemoglobin treated with peroxides. Biochem J 1992;281 ( Pt 1):197-201.

[197] Davies MJ, Puppo A. Identification of the site of the globin-derived radical in leghaemoglobins. Biochim Biophys Acta 1993;1202(2):182-8.

[198] Chen YR, Gunther MR, Mason RP. An electron spin resonance spin-trapping investigation of the free radicals formed by the reaction of mitochondrial cytochrome c oxidase with H2O2. J Biol Chem 1999;274(6):3308-14.

[199] DeGray JA, Lassmann G, Curtis JF, Kennedy TA, Marnett LJ, Eling TE, Mason RP. Spectral analysis of the protein-derived tyrosyl radicals from prostaglandin $\mathrm{H}$ synthase. J Biol Chem 1992;267(33):23583-8.

[200] Lassmann G, Curtis J, Liermann B, Mason RP, Eling TE. ESR studies on reactivity of protein-derived tyrosyl radicals formed by prostaglandin $\mathrm{H}$ synthase and ribonucleotide reductase. Arch Biochem Biophys 1993;300(1):132-6.

[201] Lassmann G, Odenwaller R, Curtis JF, DeGray JA, Mason RP, Marnett LJ, Eling TE. Electron spin resonance investigation of tyrosyl radicals of prostaglandin $\mathrm{H}$ synthase. Relation to enzyme catalysis. J Biol Chem 1991;266(30):20045-55.

[202] Babcock GT, Espe M, Hoganson C, LydakisSimantiris N, McCracken J, Shi WJ, Styring S, Tommos C, Warncke K. Tyrosyl radicals in enzyme catalysis: Some 
properties and a focus on photosynthetic water oxidation. Acta Chem Scand 1997;51(5):533-540.

[203] Barry BA. Tyrosyl Radicals in Photosystem-II. Redox-Active Amino Acids in Biology 1995;258:303-319.

[204] Bender CJ, Sahlin M, Babcock GT, Barry BA, Chandrashekar TK, Salowe SP, Stubbe J, Lindstroem B, Petersson L. An ENDOR study of the tyrosyl free radical in ribonucleotide reductase from Escherichia coli. J Am Chem Soc 1989;111(21):80768083.

[205] Gunther MR, Tschirret-Guth RA, Witkowska HE, Fann YC, Barr DP, Ortiz De Montellano PR, Mason RP. Site-specific spin trapping of tyrosine radicals in the oxidation of metmyoglobin by hydrogen peroxide. Biochem J 1998;330 ( Pt 3):12939.

[206] Barr DP, Gunther MR, Deterding LJ, Tomer KB, Mason RP. ESR spin-trapping of a protein-derived tyrosyl radical from the reaction of cytochrome $\mathrm{c}$ with hydrogen peroxide. J Biol Chem 1996;271(26):15498-15503.

[207] Ayala I, Range K, York D, Barry BA. Spectroscopic properties of tyrosyl radicals in dipeptides. J Am Chem Soc 2002;124(19):5496-5505.

[208] Bernard MT, Macdonald GM, Nguyen AP, Debus RJ, Barry BA. A Difference Infrared Study of Hydrogen-Bonding to the Z-Center-Dot Tyrosyl Radical of Photosystem-Ii. J Biol Chem 1995;270(4):1589-1594.

[209] Berthomieu C, Hienerwadel R. Vibrational spectroscopy to study the properties of redox-active tyrosines in photosystem II and other proteins. Biochim Biophys Acta 2005;1707(1):51-66.

[210] Zabelin AA, Shkuropatova VA, Shuvalov VA, Shkuropatov AY. FTIR spectroscopy of the reaction center of Chloroflexus aurantiacus: photooxidation of the primary electron donor. Biochemistry (Mosc) 2012;77(2):157-64.

[211] Zhang H, Razeghifard MR, Fischer G, Wydrzynski T. A time-resolved FTIR difference study of the plastoquinone QA and redox-active tyrosine YZ interactions in photosystem II. Biochemistry 1997;36(39):11762-8.

[212] Kadlcik V, Sicard-Roselli U, Mattioli TA, Kodicek M, Houee-Levin C. One-electron oxidation of beta-amyloid peptide: Sequence modulation of reactivity. Free Radic Biol Med 2004;37(6):881-891.

[213] Barreto WJ, Barreto SRG, Ando RA, Santos PS, DiMauro E, Jorge T. Raman, IR, UV-vis and EPR characterization of two copper dioxolene complexes derived from Ldopa and dopamine. Spectrochimica Acta Part a-Molecular and Biomolecular Spectroscopy 2008;71(4):1419-1424.

[214] Paz MA, Fluckiger R, Boak A, Kagan HM, Gallop PM. Specific detection of quinoproteins by redox-cycling staining. J Biol Chem 1991;266(2):689-92.

[215] Paz MA, Gallop PM, Torrelio BM, Fluckiger R. The Amplified Detection of Free and Bound Methoxatin (Pqq) with Nitroblue Tetrazolium Redox Reactions - Insights into the Pqq-Locus. Biochem Biophys Res Commun 1988;154(3):1330-1337.

[216] Rodgers KJ, Hume PM, Dunlop RA, Dean RT. Biosynthesis and turnover of DOPAcontaining proteins by human cells. Free Radic Biol Med 2004;37(11):1756-64.

[217] Gay C, Collins J, Gebicki JM. Hydroperoxide assay with the ferric-xylenol orange complex. Anal Biochem 1999;273(2):149-55.

[218] Winterbourn CC, Kettle AJ. Radical-radical reactions of superoxide: a potential route to toxicity. Biochem Biophys Res Commun 2003;305(3):729-36.

[219] Jessup W, Dean RT, Gebicki JM, Lester P. [29] Iodometric determination of hydroperoxides in lipids and proteins. Methods Enzymol. Volume Volume 233: Academic Press; 1994. p 289-303. 
[220] Gay CA, Gebicki JM. Measurement of protein and lipid hydroperoxides in biological systems by the ferric-xylenol orange method. Anal Biochem 2003;315(1):29-35.

[221] Khan J, Brennand DM, Bradley N, Gao B, Bruckdorfer R, Jacobs M. 3-Nitrotyrosine in the proteins of human plasma determined by an ELISA method. Biochem $\mathrm{J}$ 1998;332 (Pt 3):807-8.

[222] ter Steege JCA, Koster-Kamphuis L, van Straaten EA, Forget PP, Buurman WA. Nitrotyrosine in plasma of celiac disease patients as detected by a new sandwich ELISA. Free Radic Biol Med 1998;25(8):953-963.

[223] Franze T, Weller MG, Niessner R, Poschl U. Enzyme immunoassays for the investigation of protein nitration by air pollutants. Analyst 2003;128(7):824-31.

[224] Banks BA, Ischiropoulos H, McClelland M, Ballard PL, Ballard RA. Plasma 3nitrotyrosine is elevated in premature infants who develop bronchopulmonary dysplasia. Pediatrics 1998;101(5):870-874.

[225] Thom SR, Xu YA, Ischiropoulos H. Vascular endothelial cells generate peroxynitrite in response to carbon monoxide exposure. Chem Res Toxicol 1997;10(9):1023-31.

[226] Jin HJ, Webb-Robertson BJ, Peterson ES, Tan RM, Bigelow DJ, Scholand MB, Hoidal JR, Pounds JG, Zangar RC. Smoking, COPD, and 3-Nitrotyrosine Levels of Plasma Proteins. Environmental Health Perspectives 2011;119(9):1314-1320.

[227] Griffiths HR, Aldred S, Dale C, Nakano E, Kitas GD, Grant MG, Nugent D, Taiwo FA, Li L, Powers HJ. Homocysteine from endothelial cells promotes LDL nitration and scavenger receptor uptake. Free Radic Biol Med 2006;40(3):488-500.

[228] He K, Nukada H, McMorran PD, Murphy MP. Protein carbonyl formation and tyrosine nitration as markers of oxidative damage during ischaemia-reperfusion injury to rat sciatic nerve. Neuroscience 1999;94(3):909-916.

[229] Sultana R, Butterfield DA. Proteomics identification of carbonylated and HNE-bound brain proteins in Alzheimer's disease. Methods Mol Biol 2009;566:123-35.

[230] Soderling AS, Hultman L, Delbro D, Hojrup P, Caidahl K. Reduction of the nitro group during sample preparation may cause underestimation of the nitration level in 3nitrotyrosine immunoblotting. J Chromatogr B 2007;851(1-2):277-286.

[231] Dragusanu M, Petre BA, Przybylski M. Epitope motif of an anti-nitrotyrosine antibody specific for tyrosine-nitrated peptides revealed by a combination of affinity approaches and mass spectrometry. J Pept Sci 2010.

[232] Kato $\mathrm{Y}, \mathrm{Wu} \mathrm{X}$, Naito $\mathrm{M}$, Nomura $\mathrm{H}$, Kitamoto $\mathrm{N}$, Osawa $\mathrm{T}$. Immunochemical detection of protein dityrosine in atherosclerotic lesion of apo-E-deficient mice using a novel monoclonal antibody. Biochem Biophys Res Commun 2000;275(1):11-5.

[233] Atwood CS, Perry G, Zeng H, Kato Y, Jones WD, Ling KQ, Huang X, Moir RD, Wang D, Sayre LM and others. Copper mediates dityrosine cross-linking of Alzheimer's amyloid-beta. Biochemistry 2004;43(2):560-8.

[234] MacGregor HJ, Kato Y, Marshall LJ, Nevell TG, Shute JK. A copper-hydrogen peroxide redox system induces dityrosine cross-links and chemokine oligomerisation. Cytokine 2011;56(3):669-75.

[235] Kambayashi Y, Ogino K, Takemoto K, Imagama T, Takigawa T, Kimura S, Hibino Y, Hitomi Y, Nakamura H. Preparation and Characterization of a Polyclonal Antibody against Brominated Protein. J Clin Biochem Nutr 2009;44(1):95-103.

[236] Kato Y, Kawai Y, Morinaga H, Kondo H, Dozaki N, Kitamoto N, Osawa T. Immunogenicity of a brominated protein and successive establishment of a monoclonal antibody to dihalogenated tyrosine. Free Radic Biol Med 2005;38(1):2431.

[237] Tsumoto H, Taguchi R, Kohda K. Efficient identification and quantification of peptides containing nitrotyrosine by matrix-assisted laser desorption/ionization time- 
of-flight mass spectrometry after derivatization. Chem Pharm Bull (Tokyo) 2010;58(4):488-94.

[238] Khor HK, Fisher MT, Schoneich C. Potential role of methionine sulfoxide in the inactivation of the chaperone GroEL by hypochlorous acid $(\mathrm{HOCl})$ and peroxynitrite (ONOO-). J Biol Chem 2004;279(19):19486-93.

[239] Reyes JF, Fu Y, Vana L, Kanaan NM, Binder LI. Tyrosine nitration within the proline-rich region of Tau in Alzheimer's disease. Am J Pathol 2011;178(5):2275-85.

[240] Reyes JF, Geula C, Vana L, Binder LI. Selective tau tyrosine nitration in non-AD tauopathies. Acta Neuropathol 2012;123(1):119-32.

[241] Vana L, Kanaan NM, Hakala K, Weintraub ST, Binder LI. Peroxynitrite-induced nitrative and oxidative modifications alter tau filament formation. Biochemistry 2011;50(7):1203-12.

[242] Lozano-Juste J, Colom-Moreno R, Leon J. In vivo protein tyrosine nitration in Arabidopsis thaliana. J Exp Bot 2011;62(10):3501-17.

[243] Lee S, Chen Y, Luo H, Wu AA, Wilde M, Schumacker PT, Zhao Y. The first global screening of protein substrates bearing protein-bound 3,4-Dihydroxyphenylalanine in Escherichia coli and human mitochondria. J Proteome Res 2010;9(11):5705-14.

[244] Zhang X, Monroe ME, Chen B, Chin MH, Heibeck TH, Schepmoes AA, Yang F, Petritis BO, Camp DG, 2nd, Pounds JG and others. Endogenous 3,4dihydroxyphenylalanine and dopaquinone modifications on protein tyrosine: links to mitochondrially derived oxidative stress via hydroxyl radical. Mol Cell Proteomics 2010;9(6):1199-208.

[245] Bergt C, Fu X, Huq NP, Kao J, Heinecke JW. Lysine residues direct the chlorination of tyrosines in YXXK motifs of apolipoprotein A-I when hypochlorous acid oxidizes high density lipoprotein. J Biol Chem 2004;279(9):7856-66.

[246] Pennathur S, Bergt C, Shao B, Byun J, Kassim SY, Singh P, Green PS, McDonald TO, Brunzell J, Chait A and others. Human atherosclerotic intima and blood of patients with established coronary artery disease contain high density lipoprotein damaged by reactive nitrogen species. J Biol Chem 2004;279(41):42977-83.

[247] Chen Y, Chen W, Cobb MH, Zhao Y. PTMap - a sequence alignment software for unrestricted, accurate, and full-spectrum identification of post-translational modification sites. Proc Natl Acad Sci U S A. 2009;106:761-766.

[248] Lee JR, Lee SJ, Kim TW, Kim JK, Park HS, Kim DE, Kim KP, Yeo WS. Chemical approach for specific enrichment and mass analysis of nitrated peptides. Anal Chem 2009;81(16):6620-6.

[249] Ghesquiere B, Colaert N, Helsens K, Dejager L, Vanhaute C, Verleysen K, Kas K, Timmerman E, Goethals M, Libert $\mathrm{C}$ and others. In vitro and in vivo protein-bound tyrosine nitration characterized by diagonal chromatography. Mol Cell Proteomics 2009;8(12):2642-52.

[250] Petersson AS, Steen H, Kalume DE, Caidahl K, Roepstorff P. Investigation of tyrosine nitration in proteins by mass spectrometry. J Mass Spectrom 2001;36(6):616-25.

[251] Stevens SM, Jr., Prokai-Tatrai K, Prokai L. Factors that contribute to the misidentification of tyrosine nitration by shotgun proteomics. Mol Cell Proteomics 2008;7(12):2442-51.

[252] Mouls L, Silajdzic E, Haroune N, Spickett CM, Pitt AR. Development of novel mass spectrometric methods for identifying $\mathrm{HOCl}$-induced modifications to proteins. Proteomics 2009;9(6):1617-31.

[253] Tveen-Jensen K, Reis A, Mouls L, Pitt AR, Spickett CM. Reporter ion-based mass spectrometry approaches for the detection of non-enzymatic protein modifications in biological samples. J Proteomics 2013;92:71-9. 
[254] Ghesquiere B, Helsens K, Vandekerckhove J, Gevaert K. A stringent approach to improve the quality of nitrotyrosine peptide identifications. Proteomics 2011;11(6):1094-8.

[255] Helsens K, Timmerman E, Vandekerckhove J, Gevaert K, Martens L. Peptizer, a tool for assessing false positive peptide identifications and manually validating selected results. Mol Cell Proteomics 2008;7(12):2364-72.

[256] Li B, Held JM, Schilling B, Danielson SR, Gibson BW. Confident identification of 3nitrotyrosine modifications in mass spectral data across multiple mass spectrometry platforms. J Proteomics 2011;74(11):2510-21.

[257] Jones AW, Mikhailov VA, Iniesta J, Cooper HJ. Electron capture dissociation mass spectrometry of tyrosine nitrated peptides. J Am Soc Mass Spectrom 2010;21(2):26877.

[258] Mikhailov VA, Iniesta J, Cooper HJ. Top-down mass analysis of protein tyrosine nitration: comparison of electron capture dissociation with "slow-heating" tandem mass spectrometry methods. Anal Chem 2010;82(17):7283-92.

[259] Kim JK, Lee JR, Kang JW, Lee SJ, Shin GC, Yeo WS, Kim KH, Park HS, Kim KP. Selective Enrichment and Mass Spectrometric Identification of Nitrated Peptides Using Fluorinated Carbon Tags. Anal Chem 2011;83(1):157-163.

[260] Abello N, Barroso B, Kerstjens HA, Postma DS, Bischoff R. Chemical labeling and enrichment of nitrotyrosine-containing peptides. Talanta 2010;80(4):1503-12.

[261] Zhang Q, Qian WJ, Knyushko TV, Clauss TR, Purvine SO, Moore RJ, Sacksteder CA, Chin MH, Smith DJ, Camp DG, 2nd and others. A method for selective enrichment and analysis of nitrotyrosine-containing peptides in complex proteome samples. J Proteome Res 2007;6(6):2257-68.

[262] Amoresano A, Chiappetta G, Pucci P, D'Ischia M, Marino G. Bidimensional tandem mass spectrometry for selective identification of nitration sites in proteins. Anal Chem 2007;79(5):2109-17.

[263] Chiappetta G, Corbo C, Palmese A, Galli F, Piroddi M, Marino G, Amoresano A. Quantitative identification of protein nitration sites. Proteomics 2009;9(6):1524-37.

[264] Dremina ES, Li X, Galeva NA, Sharov VS, Stobaugh JF, Schoneich C. A methodology for simultaneous fluorogenic derivatization and boronate affinity enrichment of 3-nitrotyrosine-containing peptides. Anal Biochem 2011;418(2):184-96.

[265] Basso M, Samengo G, Nardo G, Massignan T, D'Alessandro G, Tartari S, Cantoni L, Marino M, Cheroni C, De Biasi S and others. Characterization of detergent-insoluble proteins in ALS indicates a causal link between nitrative stress and aggregation in pathogenesis. PLoS One 2009;4(12):e8130.

[266] Nardo G, Pozzi S, Mantovani S, Garbelli S, Marinou K, Basso M, Mora G, Bendotti C, Bonetto V. Nitroproteomics of peripheral blood mononuclear cells from patients and a rat model of ALS. Antioxid Redox Signal 2009;11(7):1559-67.

[267] Liu B, Tewari AK, Zhang L, Green-Church KB, Zweier JL, Chen YR, He G. Proteomic analysis of protein tyrosine nitration after ischemia reperfusion injury: mitochondria as the major target. Biochim Biophys Acta 2009;1794(3):476-85.

[268] Parastatidis I, Thomson L, Fries DM, Moore RE, Tohyama J, Fu X, Hazen SL, Heijnen HF, Dennehy MK, Liebler DC and others. Increased protein nitration burden in the atherosclerotic lesions and plasma of apolipoprotein A-I deficient mice. Circ Res 2007;101(4):368-76.

[269] Zhan X, Wang X, Desiderio DM. Pituitary adenoma nitroproteomics: current status and perspectives. Oxid Med Cell Longev 2013;2013:580710.

[270] Zhan X, Wang X, Desiderio DM. Mass spectrometry analysis of nitrotyrosinecontaining proteins. Mass Spectrom Rev 2013. 
[271] De Sanctis F, Sandri S, Ferrarini G, Pagliarello I, Sartoris S, Ugel S, Marigo I, Molon $\mathrm{B}$, Bronte $\mathrm{V}$. The emerging immunological role of post-translational modifications by reactive nitrogen species in cancer microenvironment. Front Immunol 2014;5:69.

[272] Molon B, Ugel S, Del Pozzo F, Soldani C, Zilio S, Avella D, De Palma A, Mauri P, Monegal A, Rescigno $\mathrm{M}$ and others. Chemokine nitration prevents intratumoral infiltration of antigen-specific T cells. J Exp Med 2011;208(10):1949-62.

[273] Shao B, Oda MN, Oram JF, Heinecke JW. Myeloperoxidase: an oxidative pathway for generating dysfunctional high-density lipoprotein. Chem Res Toxicol 2010;23(3):44754.

[274] Folkes LK, Trujillo M, Bartesaghi S, Radi R, Wardman P. Kinetics of reduction of tyrosine phenoxyl radicals by glutathione. Arch Biochem Biophys 2011;506(2):242-9.

[275] Hoey BM, Butler J. The Repair of Oxidized Amino-Acids by Antioxidants. Biochim Biophys Acta 1984;791(2):212-218.

[276] Hunter T. Protein kinases and phosphatases: the yin and yang of protein phosphorylation and signaling. Cell 1995;80(2):225-36.

[277] Domazou AS ZH, Koppenol WH. Fast repair of protein radicals by urate. Free Rad. Biol. Med. 2012;52:1929-1936.

[278] Steinmann D, Nauser T, Beld J, Tanner M, Gunther D, Bounds PL, Koppenol WH. Kinetics of tyrosyl radical reduction by selenocysteine. Biochemistry 2008;47(36):9602-7.

[279] Grune T, Blasig IE, Sitte N, Roloff B, Haseloff R, Davies KJ. Peroxynitrite increases the degradation of aconitase and other cellular proteins by proteasome. J Biol Chem 1998;273(18):10857-62.

[280] Gow AJ, Duran D, Malcolm S, Ischiropoulos H. Effects of peroxynitrite-induced protein modifications on tyrosine phosphorylation and degradation. FEBS Lett 1996;385(1-2):63-6.

[281] Chen HJ, Chang CM, Lin WP, Cheng DL, Leong MI. H2O2/nitrite-induced posttranslational modifications of human hemoglobin determined by mass spectrometry: redox regulation of tyrosine nitration and 3-nitrotyrosine reduction by antioxidants. Chembiochem 2008;9(2):312-23.

[282] Kuo WN, Kocis JM, Webb JK. Protein denitration/modification by Escherichia coli nitrate reductase and mammalian cytochrome P-450 reductase. Front Biosci 2002;7:a9-14.

[283] Koeck T, Fu X, Hazen SL, Crabb JW, Stuehr DJ, Aulak KS. Rapid and selective oxygen-regulated protein tyrosine denitration and nitration in mitochondria. J Biol Chem 2004;279(26):27257-62.

[284] Leger CL, Torres-Rasgado E, Fouret G, Carbonneau MA. First evidence for an LDLand HDL-associated nitratase activity that denitrates albumin-bound nitrotyrosine-physiological consequences. IUBMB Life 2008;60(1):73-8.

[285] Smallwood HS, Lourette NM, Boschek CB, Bigelow DJ, Smith RD, Pasa-Tolic L, Squier TC. Identification of a denitrase activity against calmodulin in activated macrophages using high-field liquid chromatography--FTICR mass spectrometry. Biochemistry 2007;46(37):10498-505.

[286] Kang M, Akbarali HI. Denitration of L-type calcium channel. FEBS Lett 2008;582(20):3033-6.

[287] Mani AR, Ippolito S, Moreno JC, Visser TJ, Moore KP. The metabolism and dechlorination of chlorotyrosine in vivo. J Biol Chem 2007;282(40):29114-21.

[288] Feeney MB, Schoneich C. Tyrosine modifications in aging. Antioxid Redox Signal 2012;17(11):1571-9. 
[289] Quint P, Reutzel R, Mikulski R, McKenna R, Silverman DN. Crystal structure of nitrated human manganese superoxide dismutase: mechanism of inactivation. Free Radic Biol Med 2006;40(3):453-8.

[290] Savvides SN, Scheiwein M, Bohme CC, Arteel GE, Karplus PA, Becker K, Schirmer RH. Crystal structure of the antioxidant enzyme glutathione reductase inactivated by peroxynitrite. J Biol Chem 2002;277(4):2779-84.

[291] Amorati R, Catarzi F, Menichetti S, Pedulli GF, Viglianisi C. Effect of ortho-SR groups on $\mathrm{O}-\mathrm{H}$ bond strength and $\mathrm{H}$-atom donating ability of phenols: A possible role for the tyr-cys link in galactose oxidase active site? J Am Chem Soc 2008;130(1):237244.

[292] Itoh S, Takayama S, Arakawa R, Furuta A, Komatsu M, Ishida A, Takamuku S, Fukuzumi S. Active site models for galactose oxidase. Electronic effect of the thioether group in the novel organic cofactor. Inorg Chem 1997;36(7):1407-1416.

[293] Rokhsana D, Howells AE, Dooley DM, Szilagyi RK. Role of the Tyr-Cys cross-link to the active site properties of galactose oxidase. Inorg Chem 2012;51(6):3513-24.

[294] Inesi G, Hua S, Xu C, Ma H, Seth M, Prasad AM, Sumbilla C. Studies of Ca2+ ATPase (SERCA) inhibition. J Bioenerg Biomembr 2005;37(6):365-8.

[295] Tong X, Evangelista A, Cohen RA. Targeting the redox regulation of SERCA in vascular physiology and disease. Curr Opin Pharmacol 2010;10(2):133-8.

[296] Cohen RA, Adachi T. Nitric-oxide-induced vasodilatation: Regulation by physiologic S-glutathiolation and pathologic oxidation of the sarcoplasmic endoplasmic reticulum calcium ATPase. Trends Cardiovasc Med 2006;16(4):109-114.

[297] Viner RI, Ferrington DA, Williams TD, Bigelow DJ, Schoneich C. Protein modification during biological aging: selective tyrosine nitration of the SERCA2a isoform of the sarcoplasmic reticulum Ca2+-ATPase in skeletal muscle. Biochem $\mathrm{J}$ 1999;340 ( Pt 3):657-69.

[298] Gutierrez-Martin Y, Martin-Romero FJ, Inesta-Vaquera FA, Gutierrez-Merino C, Henao F. Modulation of sarcoplasmic reticulum $\mathrm{Ca}(2+)$-ATPase by chronic and acute exposure to peroxynitrite. Eur J Biochem 2004;271(13):2647-57.

[299] Sharov VS, Galeva NA, Knyushko TV, Bigelow DJ, Williams TD, Schoneich C. Two-dimensional separation of the membrane protein sarcoplasmic reticulum $\mathrm{Ca}$ ATPase for high-performance liquid chromatography-tandem mass spectrometry analysis of posttranslational protein modifications. Anal Biochem 2002;308(2):32835.

[300] Bigelow DJ. Nitrotyrosine-modified SERCA2: a cellular sensor of reactive nitrogen species. Pflugers Arch 2009;457(3):701-710.

[301] Zhang H, Bhargava K, Keszler A, Feix J, Hogg N, Joseph J, Kalyanaraman B. Transmembrane nitration of hydrophobic tyrosyl peptides. Localization, characterization, mechanism of nitration, and biological implications. J Biol Chem 2003;278(11):8969-78.

[302] Sacksteder CA, Qian WJ, Knyushko TV, Wang H, Chin MH, Lacan G, Melega WP, Camp DG, 2nd, Smith RD, Smith DJ and others. Endogenously nitrated proteins in mouse brain: links to neurodegenerative disease. Biochemistry 2006;45(26):8009-22.

[303] Marla SS, Lee J, Groves JT. Peroxynitrite rapidly permeates phospholipid membranes. Proc Natl Acad Sci U S A 1997;94(26):14243-8.

[304] MacMillan-Crow LA, Greendorfer JS, Vickers SM, Thompson JA. Tyrosine nitration of c-SRC tyrosine kinase in human pancreatic ductal adenocarcinoma. Arch Biochem Biophys 2000;377(2):350-6.

[305] Kong SK, Yim MB, Stadtman ER, Chock PB. Peroxynitrite disables the tyrosine phosphorylation regulatory mechanism: Lymphocyte-specific tyrosine kinase fails to 
phosphorylate nitrated cdc2(6-20)NH2 peptide. Proc Natl Acad Sci U S A 1996;93(8):3377-82.

[306] Esposito F, Chirico G, Gesualdi NM, Posadas I, Ammendola R, Russo T, Cirino G, Cimino F. Protein kinase B activation by reactive oxygen species is independent of tyrosine kinase receptor phosphorylation and requires Src activity. J Biol Chem 2003;278(23):20828-20834.

[307] Klotz LO, Schieke SM, Sies H, Holbrook NJ. Peroxynitrite activates the phosphoinositide 3-kinase/Akt pathway in human skin primary fibroblasts. Biochem J 2000;352:219-225.

[308] Ridefelt P, Siegbahn A. Tyr1009 and Tyr1021 in the platelet-derived growth factor beta-receptor mediate agonist triggered calcium signalling. Anticancer Res 1998;18(3A):1819-25.

[309] van der Vliet A, Hristova M, Cross CE, Eiserich JP, Goldkorn T. Peroxynitrite induces covalent dimerization of epidermal growth factor receptors in A431 epidermoid carcinoma cells. J Biol Chem 1998;273(48):31860-6.

[310] Drew B, Leeuwenburgh C. Aging and the role of reactive nitrogen species. Ann N Y Acad Sci 2002;959:66-81.

[311] Mallozzi C, Di Stasi AM, Minetti M. Nitrotyrosine mimics phosphotyrosine binding to the SH2 domain of the src family tyrosine kinase lyn. FEBS Lett 2001;503(23):189-95.

[312] Moskovitz J. Roles of methionine suldfoxide reductases in antioxidant defense, protein regulation and survival. Curr Pharm Des 2005;11(11):1451-7.

[313] Vogt W. Oxidation of methionyl residues in proteins: tools, targets, and reversal. Free Radic Biol Med 1995;18(1):93-105.

[314] Go YM, Jones DP. Redox control systems in the nucleus: mechanisms and functions. Antioxid Redox Signal 2010;13(4):489-509.

[315] Puig A, Gilbert HF. Protein disulfide isomerase exhibits chaperone and anti-chaperone activity in the oxidative refolding of lysozyme. J Biol Chem 1994;269(10):7764-71.

[316] Vazquez-Torres A. Redox active thiol sensors of oxidative and nitrosative stress. Antioxid Redox Signal 2012;17(9):1201-14.

[317] Micevski D, Dougan DA. Proteolytic regulation of stress response pathways in Escherichia coli. Subcell Biochem 2013;66:105-28.

[318] Bohley P, Seglen PO. Proteases and Proteolysis in the Lysosome. Experientia 1992;48(2):151-157.

[319] Kopitar-Jerala N. The Role of Cysteine Proteinases and their Inhibitors in the HostPathogen Cross Talk. Current Protein \& Peptide Science 2012;13(8):767-775.

[320] Lamark T, Johansen T. Autophagy: links with the proteasome. Curr Opin Cell Biol 2010;22(2):192-8.

[321] Yamaguchi O, Taneike M, Otsu K. Cooperation between proteolytic systems in cardiomyocyte recycling. Cardiovascular Res 2012;96(1):46-52.

[322] Lionaki E, Tavernarakis N. Oxidative stress and mitochondrial protein quality control in aging. J Proteomics 2013;92:181-94.

[323] Davies KJA, Lin SW, Pacifici RE. Protein Damage and Degradation by Oxygen Radicals .4. Degradation of Denatured Protein. J Biol Chem 1987;262(20):9914-9920.

[324] Ravikumar B, Duden R, Rubinsztein DC. Aggregate-prone proteins with polyglutamine and polyalanine expansions are degraded by autophagy. Hum Mol Genet 2002;11(9):1107-17.

[325] Ravikumar B, Stewart A, Kita H, Kato K, Duden R, Rubinsztein DC. Raised intracellular glucose concentrations reduce aggregation and cell death caused by 
mutant huntingtin exon 1 by decreasing mTOR phosphorylation and inducing autophagy. Hum Mol Genet 2003;12(9):985-94.

[326] Geng F, Wenzel S, Tansey WP. Ubiquitin and proteasomes in transcription. Annu Rev Biochem 2012;81:177-201.

[327] Grimm S, Hohn A, Grune T. Oxidative protein damage and the proteasome. Amino Acids 2012;42(1):23-38.

[328] Grune T, Merker K, Sandig G, Davies KJ. Selective degradation of oxidatively modified protein substrates by the proteasome. Biochem Biophys Res Commun 2003;305(3):709-18.

[329] Jung T, Catalgol B, Grune T. The proteasomal system. Mol Aspects Med 2009;30(4):191-296.

[330] Diaz-Moreno I, Garcia-Heredia JM, Diaz-Quintana A, Teixeira M, De la Rosa MA. Nitration of tyrosines 46 and 48 induces the specific degradation of cytochrome $\mathrm{c}$ upon change of the heme iron state to high-spin. Biochim Biophys Acta 2011;1807(12):1616-23.

[331] Giulivi C, Davies KJ. Dityrosine and tyrosine oxidation products are endogenous markers for the selective proteolysis of oxidatively modified red blood cell hemoglobin by (the 19 S) proteasome. J Biol Chem 1993;268(12):8752-9.

[332] Du C, Anderson A, Lortie M, Parsons R, Bodnar A. Oxidative damage and cellular defense mechanisms in sea urchin models of aging. Free Radic Biol Med 2013;63:254-63.

[333] Yin D. Biochemical basis of lipofuscin, ceroid, and age pigment-like fluorophores. Free Radic Biol Med 1996;21(6):871-88.

[334] Sanchez I, Xu CJ, Juo P, Kakizaka A, Blenis J, Yuan JY. Caspase-8 is required for cell death induced by expanded polyglutamine repeats. Neuron 1999;22(3):623-633.

[335] Binder CJ. Natural IgM Antibodies Against Oxidation-Specific Epitopes. J Clin Immunol 2010;30:S56-S60.

[336] Doyle H, Mamula, MJ. . Post-translational protein modifications in antigen recognition and autoimmunity. Trends Immunol. 2001;22:443-449.

[337] Morgan PE, Sturgess AD, Davies MJ. Increased levels of serum protein oxidation and correlation with disease activity in systemic lupus erythematosus. Arthritis Rheum 2005;52(7):2069-79.

[338] Gauba V, Grunewald J, Gorney V, Deaton LM, Kang M, Bursulaya B, Ou W, Lerner RA, Schmedt C, Geierstanger BH and others. Loss of CD4 T-cell-dependent tolerance to proteins with modified amino acids. Proc Natl Acad Sci U S A 2011;108(31):12821-6.

[339] Birnboim HC, Lemay AM, Lam DKY, Goldstein R, Webb JR. Cutting edge: MHC class II-restricted peptides containing the inflammation-associated marker 3nitrotyrosine evade central tolerance and elicit a robust cell-mediated immune response. J Immunol 2003;171(2):528-532.

[340] Khan MA, Dixit K, Jabeen S, Moinuddin, Alam K. Impact of peroxynitrite modification on structure and immunogenicity of H2A histone. Scand J Immunol 2009;69(2):99-109.

[341] Ohmori H, Oka M, Nishikawa Y, Shigemitsu H, Takeuchi M, Magari M, Kanayama N. Immunogenicity of autologous IgG bearing the inflammation-associated marker 3nitrotyrosine. Immunol Lett 2005;96(1):47-54.

[342] Eilat D, Naparstek Y. Anti-DNA autoantibodies: a puzzle of autoimmune phenomena. Immunol Today 1999;20(8):339-42.

[343] Ohmori H, Kanayama N. Immunogenicity of an inflammation-associated product, tyrosine nitrated self-proteins. Autoimmun Rev 2005;4(4):224-9. 
[344] Untersmayr E, Diesner SC, Oostingh GJ, Selzle K, Pfaller T, Schultz C, Zhang Y, Krishnamurthy D, Starkl P, Knittelfelder R and others. Nitration of the egg-allergen ovalbumin enhances protein allergenicity but reduces the risk for oral sensitization in a murine model of food allergy. PLoS One 2010;5(12):e14210.

[345] Thomson L, Christie J, Vadseth C, Lanken PN, Fu X, Hazen SL, Ischiropoulos H. Identification of immunoglobulins that recognize 3-nitrotyrosine in patients with acute lung injury after major trauma. Am J Respir Cell Mol Biol 2007;36(2):152-7.

[346] Thomson L, Tenopoulou M, Lightfoot R, Tsika E, Parastatidis I, Martinez M, Greco $\mathrm{TM}$, Doulias PT, Wu Y, Tang WH and others. Immunoglobulins against tyrosinenitrated epitopes in coronary artery disease. Circulation 2012;126(20):2392-401.

[347] El-Remessy AB, Khalil IE, Matragoon S, Abou-Mohamed G, Tsai NJ, Roon P, Caldwell RB, Caldwell RW, Green K, Liou GI. Neuroprotective effect of (-)Delta9tetrahydrocannabinol and cannabidiol in N-methyl-D-aspartate-induced retinal neurotoxicity: involvement of peroxynitrite. Am J Pathol 2003;163(5):1997-2008.

[348] Kobayashi T, Taguchi K, Takenouchi Y, Matsumoto T, Kamata K. Insulin-induced impairment via peroxynitrite production of endothelium-dependent relaxation and sarco/endoplasmic reticulum $\mathrm{Ca} 2+-\mathrm{ATPase}$ function in aortas from diabetic rats. Free Radic Biol Med 2007;43(3):431-443.

[349] Ling X, Cota-Gomez A, Flores NC, Hernandez-Saavedra D, McCord JM, Marecki JC, Haskins K, McDuffie M, Powers K, Kench J and others. Alterations in redox homeostasis and prostaglandins impair endothelial-dependent vasodilation in euglycemic autoimmune nonobese diabetic mice. Free Radic Biol Med 2005;39(8):1089-98.

[350] Adachi T, Matsui R, Xu S, Kirber M, Lazar HL, Sharov VS, Schoneich C, Cohen RA. Antioxidant improves smooth muscle sarco/endoplasmic reticulum $\mathrm{Ca}(2+)$-ATPase function and lowers tyrosine nitration in hypercholesterolemia and improves nitric oxide-induced relaxation. Circ Res 2002;90(10):1114-21.

[351] Thomas MM, Vigna C, Betik AC, Tupling AR, Hepple RT. Cardiac calcium pump inactivation and nitrosylation in senescent rat myocardium are not attenuated by longterm treadmill training. Exp Gerontol 2011;46(10):803-10.

[352] Bosio G, Criado S, Massad W, Nieto FJR, Gonzalez MC, Garcia NA, Martire DO. Kinetics of the interaction of sulfate and hydrogen phosphate radicals with small peptides of glycine, alanine, tyrosine and tryptophan. Photochemical \& Photobiological Sciences 2005;4(10):840-846.

[353] Criado S, Marioli JM, Allegretti PE, Furlong J, Nieto FJR, Martire DO, Garcia NA. Oxidation of di- and tripeptides of tyrosine and valine mediated by singlet molecular oxygen, phosphate radicals and sulfate radicals. J Photochem Photobiol B 2001;65(1):74-84.

[354] Chen SN, Hoffman MZ. Rate constants for the reaction of the carbonate radical with compounds of biochemical interest in neutral aqueous solution. Radiat Res 1973;56(1):40-7.

[355] Chen SN, Z. HM. Effect of $\mathrm{pH}$ on the reactivity of the carbonate radical in aqueous solution. Radiat Res 1975;62:18-27.

[356] Clarke K, Edge R, Johnson V, Land EJ, Navaratnam S, Truscott TG. The carbonate radical: its reactivity with oxygen, ammonia, amino acids, and melanins. J Phys Chem A 2008;112(41):10147-51.

[357] Andreazza AC, Shao L, Wang JF, Young LT. Mitochondrial Complex I Activity and Oxidative Damage to Mitochondrial Proteins in the Prefrontal Cortex of Patients With Bipolar Disorder. Arch Gen Psychiatry 2010;67(4):360-368. 
[358] Tahrani AA, Ali A, Raymond NT, Begum S, Dubb K, Mughal S, Jose B, Piya MK, Barnett AH, Stevens MJ. Obstructive sleep apnea and diabetic neuropathy: a novel association in patients with type 2 diabetes. Am J Respir Crit Care Med 2012;186(5):434-41.

[359] Dong YF, Kataoka K, Tokutomi Y, Nako H, Nakamura T, Toyama K, Sueta D, Koibuchi N, Yamamoto E, Ogawa $\mathrm{H}$ and others. Beneficial effects of combination of valsartan and amlodipine on salt-induced brain injury in hypertensive rats. J Pharmacol Exp Ther 2011;339(2):358-66.

[360] Drel VR, Lupachyk S, Shevalye H, Vareniuk I, Xu W, Zhang J, Delamere NA, Shahidullah M, Slusher B, Obrosova IG. New therapeutic and biomarker discovery for peripheral diabetic neuropathy: PARP inhibitor, nitrotyrosine, and tumor necrosis factor-\{alpha\}. Endocrinology 2010;151(6):2547-55.

[361] Castegna A, Thongboonkerd V, Klein JB, Lynn B, Markesbery WR, Butterfield DA. Proteomic identification of nitrated proteins in Alzheimer's disease brain. J Neurochem 2003;85(6):1394-401.

[362] Reed TT, Owen J, Pierce WM, Sebastian A, Sullivan PG, Butterfield DA. Proteomic identification of nitrated brain proteins in traumatic brain-injured rats treated postinjury with gamma-glutamylcysteine ethyl ester: insights into the role of elevation of glutathione as a potential therapeutic strategy for traumatic brain injury. J Neurosci Res 2009;87(2):408-17.

[363] MacMillan-Crow LA, Crow JP, Kerby JD, Beckman JS, Thompson JA. Nitration and inactivation of manganese superoxide dismutase in chronic rejection of human renal allografts. Proc Natl Acad Sci U S A 1996;93(21):11853-8.

[364] Sharov VS, Pal R, Dremina ES, Michaelis EK, Schoneich C. Fluorogenic tagging of protein 3-nitrotyrosine with 4-(aminomethyl)benzene sulfonate in tissues: a useful alternative to Immunohistochemistry for fluorescence microscopy imaging of protein nitration. Free Radic Biol Med 2012;53(10):1877-85.

[365] Hoshino A, Okawa Y, Ariyoshi M, Kaimoto S, Uchihashi M, Fukai K, Iwai-Kanai E, Matoba S. Oxidative post-translational modifications develop LONP1 dysfunction in pressure overload heart failure. Circ Heart Fail 2014;7(3):500-9.

[366] Hu S, Liu H, Ha Y, Luo X, Motamedi M, Gupta MP, Ma JX, Tilton RG, Zhang W. Posttranslational Modification of Sirt6 Activity by Peroxynitrite. Free Radic Biol Med 2014.

[367] Prokai-Tatrai K, Guo J, Prokai L. Selective chemoprecipitation and subsequent release of tagged species for the analysis of nitropeptides by liquid chromatography-tandem mass spectrometry. Mol Cell Proteomics 2011;10(8):M110 002923. 
Table 1. Rate constants for oxidation of free or protein-bound Tyr by free radicals $(\mathrm{R} \bullet)$.

\begin{tabular}{|c|c|c|c|c|}
\hline $\mathbf{R}^{\circ}$ & $\left.\mathbf{k}\left(\mathbf{R}^{\bullet}+\mathrm{Tyr}\right) \mathrm{mol}^{-1} \mathbf{L} \mathbf{s}^{-1}\right)$ & $\begin{array}{l}\text { Radical } \\
\text { formed }\end{array}$ & Final product(s) & References \\
\hline $\mathrm{OH}^{*}$ & $\begin{array}{l}\text { pH 2.2: }(5.8 \pm 0.3) \times 10^{9} \\
\text { pH 4.6: }(3.7 \pm 0.6) \times 10^{9} \\
\text { pH 7.5: } 1.3 \times 10^{10} \\
\text { pH 10.6: }(2.2 \pm 0.5) \times 10^{10}\end{array}$ & $\begin{array}{l}\text { Mostly } \\
\text { OH- } \\
\text { adducts on } \\
\text { o- or m- } \\
\text { positions }\end{array}$ & $\begin{array}{l}\text { Mostly } \\
\text { dihydroxyphenylalanine } \\
(3,4 \text { DOPA })^{\text {a }} \\
\text { DiTyr }^{\text {b }}\end{array}$ & $\begin{array}{l}{[22-} \\
25,296]\end{array}$ \\
\hline & $\begin{array}{l}\text { Neutral: } 3.6 \times 10^{9} \\
\text { Alkaline: } 1 \times 10^{8}\end{array}$ & & & {$[35]$} \\
\hline $\mathrm{N}_{3}{ }^{\circ}$ & $\begin{array}{l}\text { N-Ac-Tyr-amide: } 1.3-1.7 \times 10^{8} \\
\text { Chymotrypsin-Tyr }(3 \pm 0.5) \times 10^{8} \\
\text { BSA-Tyr }(4.7 \pm 0.3) \times 10^{8}\end{array}$ & TyrO & DiTyr & {$[36]$} \\
\hline $\begin{array}{l}\mathrm{Cl}_{2}^{\circ-} \\
\mathrm{Br}_{2}^{\circ-} \\
\mathrm{I}_{2}^{--} \\
(\mathrm{SCN})_{2}{ }^{\circ-}\end{array}$ & $\begin{array}{l}2.7 \times 10^{8} \\
2.0 \times 10^{7} \\
<1.0 \times 10^{6} \\
5.0 \times 10^{6} \\
\end{array}$ & TyrO` & & {$[38]$} \\
\hline $\mathrm{SO}_{4}^{\circ-}$ & $\begin{array}{l}5.8 \times 10^{8} \mathrm{c} \\
(0.4-1.2) \times 10^{9} \mathrm{~d} \\
(1.2-2.7) \times 10^{10} \quad \mathrm{e}\end{array}$ & $\begin{array}{l}\mathrm{SO}_{4}^{*-} \\
\text { adducts }\end{array}$ & & {$[150]$} \\
\hline $\mathrm{HPO}_{4}{ }^{-}$ & $\begin{array}{l}4.0 \times 10^{8} \mathrm{c} \\
(2.2-5.9) \times 10^{8} \mathrm{~d} \\
(2.0-2.1) \times 10^{9} \mathrm{e}\end{array}$ & & & {$[352,353]$} \\
\hline $\mathrm{PO}_{4}^{\cdot 2-}$ & $(1.0-1.4) \times 10^{8} \quad \mathrm{c}, \mathrm{d}$ & +2 & & {$[352,353]$} \\
\hline $\mathrm{CO}_{3}{ }^{-}$ & $\begin{array}{l}\text { pH 7: } 4.5 \times 10^{7} \\
\text { pH 11: } 1.4 \times 10^{8}\end{array}$ & $\begin{array}{ll}\text { TyrO } \\
\text { Adduct }\end{array}$ & & $\begin{array}{l}354,355] \\
{[355,356]} \\
\end{array}$ \\
\hline $\mathrm{ClO}_{2}{ }^{--}$ & $\begin{array}{l}\text { Tyr: } 1.8 \times 10^{5} \\
\text { N-Ac-Tyr: } 3.2 \times 10^{4} \\
\text { Basic medium: } \\
(8.2-18) \times 10^{7} \mathrm{c} \\
7.6 \times 10^{7} \mathrm{f} \\
\end{array}$ & TyrO & $\begin{array}{l}3,4- \\
\text { dihydroxyphenylalanine } \\
\text { (DOPA) and 2,4,5- } \\
\text { trihydroxyphenylalanine } \\
\text { (TOPA) }\end{array}$ & {$[39-42]$} \\
\hline $\mathrm{NO}_{2}^{-}$ & $\begin{array}{c}(2.9 \pm 0.3) \times 10^{7}{ }^{\mathrm{c}} \\
\mathrm{pH} 7.5: 3.2 \times 10^{5} \\
2.0 \times 10^{7} \mathrm{~g}\end{array}$ & $\mathrm{TyrO}^{\bullet}$ & $\begin{array}{l}\text { 3,3'-diTyr or } \\
\text { 3-nitroTyr }\end{array}$ & {$[41,47]$} \\
\hline$-\mathrm{NH}_{2}$ & $8 \times 10^{6}$ & & 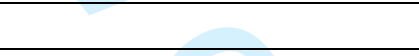 & {$[356]$} \\
\hline $\begin{array}{l}\text { Lipid } \\
\text { Peroxyl } \\
\text { radicals } \\
(\mathrm{LOO} \bullet)\end{array}$ & $\begin{array}{l}\text { N-t-Boc-L-Tyr-tert-butyl ester } \\
\text { in liposomes: } 4.8 \times 10^{3}\end{array}$ & $\mathrm{TyrO}^{\circ}$ & & {$[58]$} \\
\hline $\mathrm{RO} \bullet$ & $\begin{array}{l}t-\mathrm{BuO}^{\circ} \text { in neutral medium: } \\
\sim 3 \times 10^{5} \\
\text { In basic medium: } \sim 2 \times 10^{8}\end{array}$ & TyrO & & {$[59]$} \\
\hline $\begin{array}{l}\text { Phenoxyl } \\
\text { radicals } \\
\left(\mathrm{PhO}^{*}\right)\end{array}$ & In ionized state: $4.9 \times 10^{8}$ & & & {$[60]$} \\
\hline $\begin{array}{l}\text { a In glycyl p } \\
{ }^{\mathrm{b}} \text { In Tyr, Gl } \\
{ }^{\mathrm{c}} \text { In Tyr ami } \\
{ }^{\mathrm{d}} \text { In Val-con } \\
{ }^{\mathrm{e}} \text { In Gly con } \\
{ }^{\mathrm{f}} \text { In N-Ac-T }\end{array}$ & $\begin{array}{l}\text { pptides and in various proteins } \\
\text {-Tyr and poly-L-Tyr and in protein } \\
\text { no acid in solution } \\
\text { taining peptides } \\
\text { aining peptides } \\
\text { r; g) in Gly Tyr. }\end{array}$ & sulin, ribon & ase, papain, collagen, and lys & yme) \\
\hline
\end{tabular}


Table 2. Rate constants for reaction of Tyr-derived radicals (TyrO•, Tyr-OH adduct) with various radical or molecular reactants.

\begin{tabular}{|c|c|c|c|}
\hline Reactants & Products & $\begin{array}{l}\text { Rate constant } \\
\left(\mathrm{mol}^{-1} \mathrm{~L} \mathrm{~s}^{-1}\right)\end{array}$ & Reference \\
\hline $\mathrm{TyrO}^{\bullet}+$ itself & $\begin{array}{l}\text { o-DiTyr } \\
\text { m-DiTyr }\end{array}$ & $\begin{array}{l}3.0 \times 10^{8 \mathrm{a}} \\
2.0 \times 10^{9} \mathrm{a} \\
4.5 \times 10^{8 \mathrm{a}} \\
4.7 \times 10^{8 \mathrm{~b}} \\
3.6 \times 10^{8 \mathrm{c}} \\
5.1 \times 10^{8 \mathrm{~d}}\end{array}$ & {$[22,23,26,67]$} \\
\hline Tyr-OH adduct $+\mathrm{O}_{2}$ & Peroxyl radical & $5 \times 10^{8}$ to $10^{9}$ & [26] \\
\hline $\mathrm{TyrO}^{\circ}+\mathrm{O}_{2}$ & & $<10^{3}$ & [28] \\
\hline $\begin{array}{l}\text { TyrO }+ \text { phenoxide } \\
\text { (PheO-) }\end{array}$ & $\begin{array}{l}\text { TyrO- }^{-} \text {(tyrosine anion) }+ \\
\text { PheO }^{-}\end{array}$ & $2.8 \times 10^{7}$ & [60] \\
\hline $\mathrm{TyrO}^{\circ}+\mathrm{NO}$ & 3-nitrosoTyr & $(1-2) \times 10^{9} \mathrm{e}$ & {$[98,99]$} \\
\hline $\mathrm{TyrO}^{\circ}+\mathrm{NO}_{2}{ }^{\circ}$ & 3-nitroTyr & $\begin{array}{l}\text { Ca. } 3 \times 10^{9} \mathrm{a} \\
3.0 \times 10^{7} \mathrm{~b} \\
(\text { at } \mathrm{pH} 9.3) \\
3 \times 10^{4} \mathrm{f} \\
9 \times 10^{2} \mathrm{~g}\end{array}$ & {$[100,101]$} \\
\hline $\mathrm{TyrO}^{\bullet}+\mathrm{O}_{2}^{{ }^{-}}$ & $\begin{array}{l}\text { Adduct at } \mathrm{o}-\text { or } \mathrm{p}- \\
\text { positions }\end{array}$ & $\begin{array}{l}(1.6 \pm 0.1) \times 10^{9} \mathrm{a} \\
(1.5-1.7) \times 10^{9} \mathrm{c} \\
2.5 \times 10^{9} \mathrm{~d}\end{array}$ & {$[27,67,114]$} \\
\hline $\begin{array}{l}\text { a With Tyr amino acid } \\
\text { b } \text { With Gly Tyr } \\
\text { c With Met enkephalin } \\
\text { d } \text { With Boc Met enkeph } \\
\text { e } \text { With Tyr, N-acetyl Ty } \\
\text { f } \\
\text { g Y121 in ribonucleotid } \\
\text { g In ribonucleotide redu }\end{array}$ & $\begin{array}{l}\text { in } \\
\text { and Gly Tyr } \\
\text { eductase } \\
\text { ase, Y residues other than }\end{array}$ & 8 & \\
\hline
\end{tabular}


Table 3. Detection of nitrotyrosine in various pathologies

\begin{tabular}{llll}
\hline Pathology /tissue/fluid & Method of detection & References \\
\hline $\begin{array}{l}\text { Plasma of infants with } \\
\text { bronchopulmonary dysplasia }\end{array}$ & Solid phase ELISA & {$[224]$} \\
\hline $\begin{array}{l}\text { Carbon monoxide-exposed } \\
\text { endothelium }\end{array}$ & Solid phase ELISA & {$[225]$} \\
\hline Bipolar disorders \& Schizophrenia & ELISA & {$[357]$} \\
\hline $\begin{array}{l}\text { Type 2 diabetes with obstrusive } \\
\text { sleep apnea }\end{array}$ & ELISA & {$[358]$} \\
\hline Rat brain following high salt loading & ELISA for free 3-nitro-Tyr & {$[359]$} \\
\hline $\begin{array}{l}\text { Nervous tissue of streptozotocin } \\
\text { diabetic rats }\end{array}$ & $\begin{array}{l}\text { Double-label fluorescent } \\
\text { immunohistochemistry }\end{array}$ & {$[360]$} \\
\hline $\begin{array}{l}\text { Neurodegenerative diseases } \\
\text { (Alzheimer's disease \& ALS) }\end{array}$ & Western blotting & {$[265,266,361,362]$} \\
\hline $\begin{array}{l}\text { Coronary vessel atherosclerotic } \\
\text { plaques \& pancreatic } \\
\text { adenocarcinoma }\end{array}$ & $\begin{array}{l}\text { Western blotting, IP and MS } \\
\text { sequencing techniques }\end{array}$ & {$[304,363]$} \\
\hline $\begin{array}{l}\text { Mouse models of cardiovascular } \\
\text { dysfunction }\end{array}$ & Western blotting, IP and MS & {$[267,268]$} \\
\hline $\begin{array}{l}\text { Rat Cerebellar Purkinje cells } \\
\text { sequencing techniques }\end{array}$ & $\begin{array}{l}\text { Fluorogenic tagging strategy } \\
\text { with MS }\end{array}$ & {$[364]$} \\
\hline $\begin{array}{l}\text { Mouse model of heart failure } \\
\text { (LONP1 nitration) }\end{array}$ & \begin{tabular}{l} 
Immunoblotting \\
\hline inflammation (Sirt6 nitration)
\end{tabular} & Western blotting & {$[365]$} \\
\hline
\end{tabular}


Table 4. Labelling and enrichment strategies for detection of oxidized or nitrated tyrosine

\begin{tabular}{|c|c|c|c|}
\hline Label & Enrichment or detection method & Tissue / samples assayed & References \\
\hline $\begin{array}{l}N \text {-succinimidyl } S \text { - } \\
\text { acetylthioacetate (SATA) }\end{array}$ & $\begin{array}{l}\text { Removal of the } S \text {-acetyl group after labelling } \\
\text { exposed free thiol groups, for binding to a } \\
\text { thiopropyl sepharose. }\end{array}$ & Mouse brain homogenate & {$[261]$} \\
\hline $\begin{array}{l}\text { 4-formylbenzoyl-amido } \\
\text { (FBA) }\end{array}$ & $\begin{array}{l}\text { Chemoprecipitation, captured on a Solid Phase } \\
\text { Active Ester Resin (SPAER) }\end{array}$ & $\begin{array}{l}\text { Human plasma nitrated } \\
\text { with tetranitromethane }\end{array}$ & {$[367]$} \\
\hline $\begin{array}{l}(3 \mathrm{R}, 4 \mathrm{~S})-1-(4-(\text { amino- } \\
\text { methyl) phenylsulfonyl) } \\
\text { pyrrolidine-3,4-diol } \\
\text { (APPD) }\end{array}$ & $\begin{array}{l}\text { Strong retention on sulfonamide phenylboronic } \\
\text { acid columns compared to native proteins ; } \\
\text { fluorescent tag gave diagnostic } \mathrm{m} / \mathrm{z} \text { increase and } \\
\text { fragment ions }\end{array}$ & $\begin{array}{l}\text { Total protein lysate of } \\
\text { cultured } \mathrm{C} 2 \mathrm{Cl} 2 \text { cells } \\
\text { cerebellar Purkinje cells }\end{array}$ & {$[264,364]$} \\
\hline Biotinylation & $\begin{array}{l}\text { Enriched on avidin immobilized agarose beads; a } \\
\text { simple 1-buffer system approach }\end{array}$ & $\begin{array}{l}\text { Peroxynitrite-treated } \\
\text { angiotensin in a mixture } \\
\text { of BSA peptides }\end{array}$ & [260] \\
\hline $\begin{array}{l}\text { Pyridine-2-carboxaldehyde } \\
+ \text { cyanoborohydride } \\
\text { labelling }\end{array}$ & $\begin{array}{l}\text { Labelled peptides were enriched by immobilized } \\
\text { metal ion affinity chromatography }\left(\mathrm{Ni}^{2+}\right. \\
\text { nitrilotriacetic acid magnetic beads) }\end{array}$ & $\begin{array}{l}\text { E. coli lysate and HeLa } \\
\text { cell mitochondria }\end{array}$ & [248] \\
\hline $\begin{array}{l}\text { N-succinimidyl 3- } \\
\text { (perfluorobutyl) propionate }\end{array}$ & $\begin{array}{l}\text { Combined with fluorinated solid phase extraction } \\
\text { (FSPE) }\end{array}$ & $\begin{array}{l}\text { Proteins in a Huh } 7 \text { cell } \\
\text { lysate, in the absence of } \\
\text { induced nitrative stress }\end{array}$ & [259] \\
\hline Dansyl chloride & $\begin{array}{l}\text { Used as a "reporter ion generation tag" (RIGhT) } \\
\text { owing to diagnostic fragment ions / transitions }\end{array}$ & $\begin{array}{l}\text { Nitrated BSA as a model } \\
\text { protein }\end{array}$ & {$[262]$} \\
\hline iTRAQ labelling reagents & $\begin{array}{l}\text { Labels were released in } \mathrm{MS}^{2} \text { and detected at } m / z \\
114 / 115 / 116 / 117\end{array}$ & $\begin{array}{l}\text { E. coli and bovine milk } \\
\text { extract }\end{array}$ & [263] \\
\hline
\end{tabular}


Table 5. Rate constants for reaction of TyrO with reducing agents.

\begin{tabular}{|c|c|c|}
\hline Repair agent & Rate constant $\left(\mathrm{mol}^{-1} \mathrm{~L} \mathrm{~s}^{-1}\right)$ & References \\
\hline Ascorbate & $\begin{array}{l}(0.9-4.4) \times 10^{7} \mathrm{a} \\
(2.6 \pm 0.2) \times 10^{8} \mathrm{~b} \\
(2.9 \pm 0.1) \times 10^{7} \mathrm{c} \\
4.0 \times 10^{7} \mathrm{~d} \\
(3.5 \pm 0.9) \times 10^{7} \mathrm{e} \\
(4.0 \pm 0.6) \times 10^{5} \mathrm{f} \\
1.1 \times 10^{7} \mathrm{~g}\end{array}$ & $\begin{array}{l}{[28]} \\
{[275]} \\
{[34]}\end{array}$ \\
\hline GSH & $\begin{array}{l}2 \times 10^{6} \mathrm{a} \\
(2.4 \pm 1.6) \times 10^{3} \mathrm{~b} \\
(1.0 \pm 0.6) \times 10^{4} \mathrm{c}\end{array}$ & $\begin{array}{l}{[274]} \\
{[128]}\end{array}$ \\
\hline Cysteine & $\begin{array}{l}(6 \pm 3) \times 10^{5} \mathrm{~b} \\
(1.0 \pm 0.6) \times 10^{5} \mathrm{c}\end{array}$ & {$[128]$} \\
\hline Selenoglutathione & $\begin{array}{l}(5 \pm 2) \times 10^{8 b} \\
(4.0 \pm 3) \times 10^{6} \mathrm{c}\end{array}$ & [278] \\
\hline Selenocysteine & $\begin{array}{l}(8 \pm 2) \times 10^{8} b \\
(1.6 \pm 0.8) \times 10^{8} \mathrm{c}\end{array}$ & [278] \\
\hline Urate & $\begin{array}{l}2.4 \times 10^{8} \mathrm{a} \\
<1 \times 10^{6 \mathrm{~d}} \\
3 \times 10^{8} \mathrm{e} \\
5.4 \times 10^{6} \mathrm{~g}\end{array}$ & {$[28,275,277]$} \\
\hline Trolox & $3.1 \times 10^{8}$ & {$[28]$} \\
\hline \multicolumn{3}{|c|}{$\begin{array}{ll}\text { a } & \text { For Tyr free amino a } \\
\text { b } & \text { For N-Ac-Tyr-NH } \\
\text { c } & \text { For insulin } \\
\text { d } & \text { For chymotrypsin } \\
\text { e } & \text { For pepsin } \\
\text { f } & \text { For lactoglobulin } \\
\text { g } & \text { For lysosyme in the }\end{array}$} \\
\hline
\end{tabular}




\section{Figure Legends}

Figure 1. Photo-oxidation of Tyr by direct absorption of energy to produce electronically excited states and photo-ionized species. The electrically excited state can react with oxygen or disulfides to give $\mathrm{TyrO}^{\bullet}$, which may then react together to give different cross-linked products. Reaction of free Tyr with singlet oxygen following photo-sensitizationcan lead to the formation of endoperoxides, followed by rearrangement and generation of cyclization products.

Figure 2. Reactions of $\mathrm{TyrO}^{\bullet}$ with the superoxide radical anion. (A) For a residue which is within a polypeptide chain or close to the C-terminal; (B) for a residue which is either $\mathrm{N}$ terminal or a free tyrosyl radical.

Figure 3. The thioether bond between Cys228 and Tyr272 in galactose oxidase (PDB 1GOF) [124].

Figure 4. Examples of protein free radicals that can be reduced by a Tyr residue, leading to formation of a tyrosine phenoxyl radical $\left(\mathrm{TyrO}^{\circ}\right)$ and regeneration of the other amino acids. Top row, left to right: tryptophan-derived indolyl radical ; cysteine-derived thiyl radical; histidine-derived imidazole radical-cation. Bottom row, left to right: methionine-derived sulfur-centered radical-cation; three-electron-bonded sulfur-bromine radical species from methionine; three-electron-bonded cyclized sulfur-nitrogen species from methionine.

Figure 5. Mass spectrometry approaches to analysis of Tyr oxidation. Proteins containing oxidized Tyr can be separated by immuno-enrichment with specific antibodies, and subjected to label-dependent or -independent methods for mass spectrometry analysis. Label-free methods use the change in mass-to-charge ratio $(\mathrm{m} / \mathrm{z})$ resulting from the modification to characterize the oxidation, while label-dependent methods are mostly used for 3-nitroTyr following reduction to 3-aminoTyr. They can then be used either for targeted enrichment, or label-dependent MS analysis, or both. In most cases, peptide fragmentation by MSMS is used to determine the sequence of the modified peptide with search engines such as Mascot by reference to a database of protein sequences. 
Figure 6. The two Tyr residues in SERCA that have been reported to be nitrated are Tyr294 and Tyr295.

Figure 7. The possible fates of oxidized Tyr in proteins. 
1

2

3

4

5

6

7

8

9

10

11

12

13

14

15

16

17

18

19

20

21

22

23

24

25

26

27

28

29

30

31

32

33

34

35

36

37

38

39

40

41

42

43

44

45

46

47

48

49

50

51

52

53

54

55

56

57

58

59

60

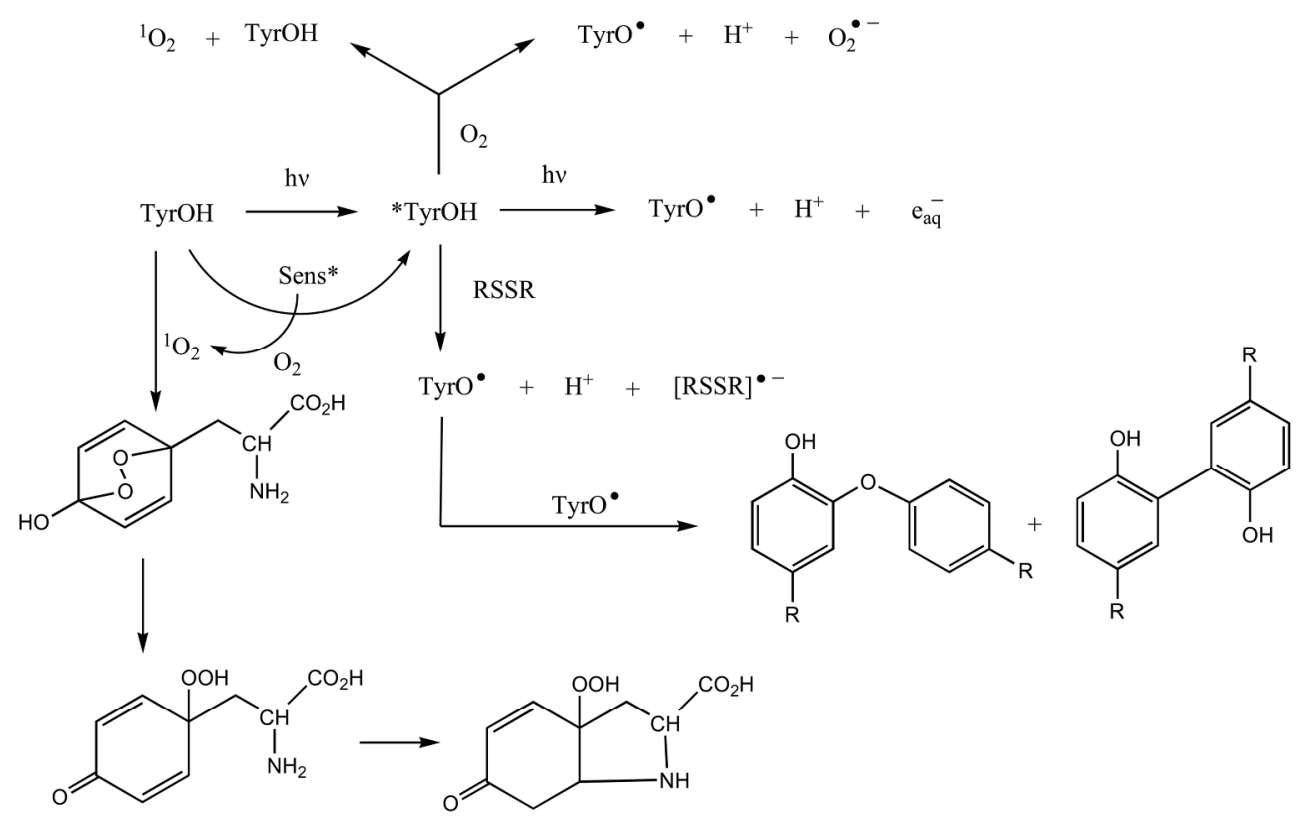

Figure 1. Photo-oxidation of Tyr by direct absorption of energy to produce electronically excited states and photo-ionized species. The electrically excited state can react with oxygen or disulfides to give TyrO•, which may then react together to give different cross-linked products. Reaction of free Tyr with singlet oxygen following photo-sensitizationcan lead to the formation of endoperoxides, followed by rearrangement and generation of cyclization products. $106 \times 68 \mathrm{~mm}(600 \times 600 \mathrm{DPI})$ 
Figure 2. Reactions of TyrO• with the superoxide radical anion. (A) For a residue which is within a polypeptide chain or close to the C-terminal; (B) for a residue which is either $\mathrm{N}$-terminal or a free tyrosyl radical. $144 \times 151 \mathrm{~mm}(300 \times 300 \mathrm{DPI})$ 


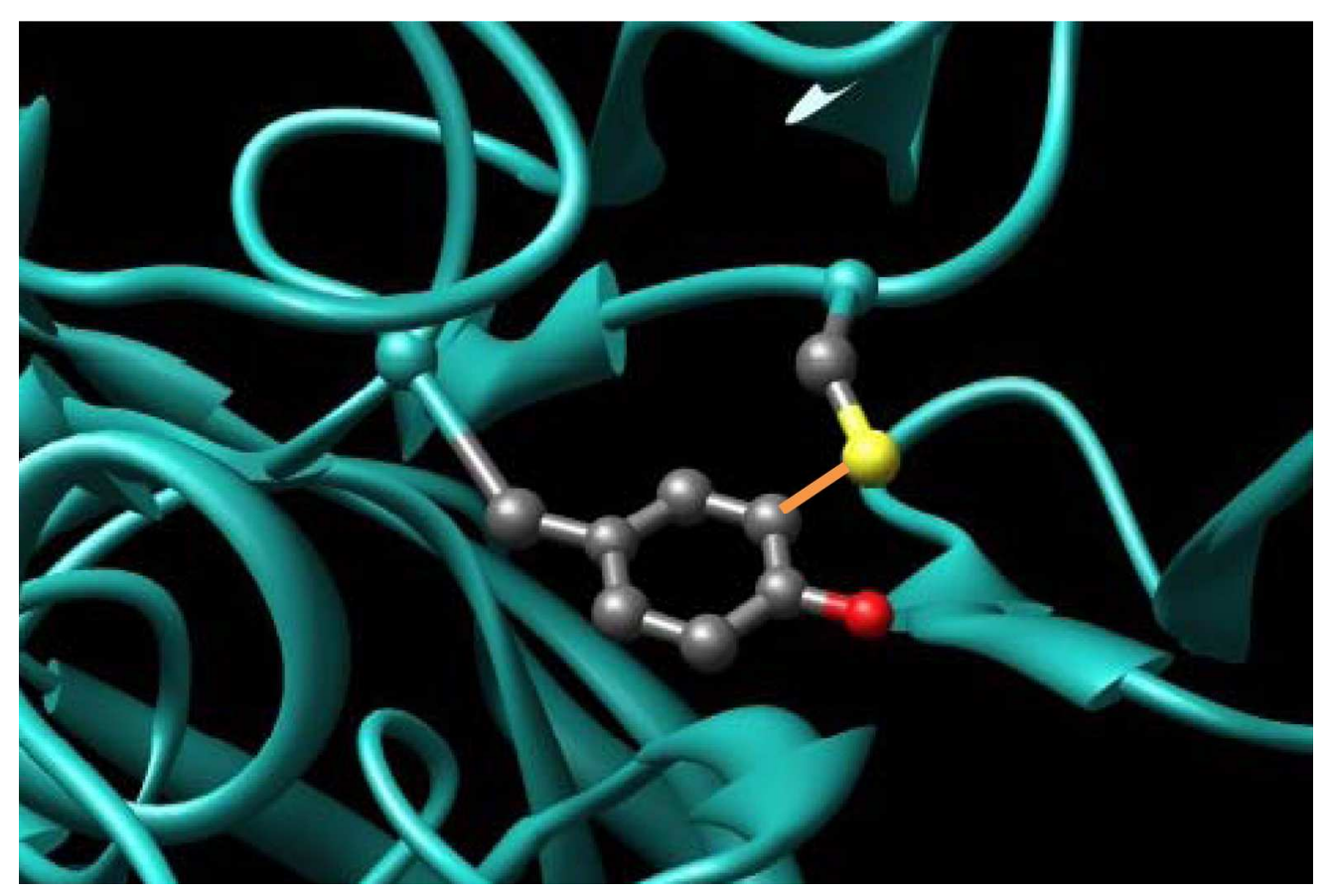

Figure 3. The thioether bond between Cys228 and Tyr272 in galactose oxidase (PDB 1GOF) [124]. $78 \times 52 \mathrm{~mm}(600 \times 600$ DPI $)$ 
<smiles>CNC(=O)C(Cc1cn(C)c2ccccc12)NC</smiles><smiles>CNC(CS)C(N)=O</smiles><smiles>CNC(Cc1c[nH]cn1)C(N)=O</smiles><smiles>C[S+](Br)CCC(N)C(N)=O</smiles><smiles>C[S]1CCC(C(N)=O)N1</smiles>

\section{Methionine-derived radicals}

Figure 4. Examples of protein free radicals that can be reduced by a Tyr residue, leading to formation of a tyrosine phenoxyl radical (TyrO•) and regeneration of the other amino acids. Top row, left to right: tryptophan-derived indolyl radical ; cysteine-derived thiyl radical; histidine-derived imidazole radical-cation. Bottom row, left to right: methionine-derived sulfur-centered radical-cation; three-electron-bonded sulfurbromine radical species from methionine; three-electron-bonded cyclized sulfur-nitrogen species from methionine.

$109 \times 88 \mathrm{~mm}(600 \times 600 \mathrm{DPI})$ 


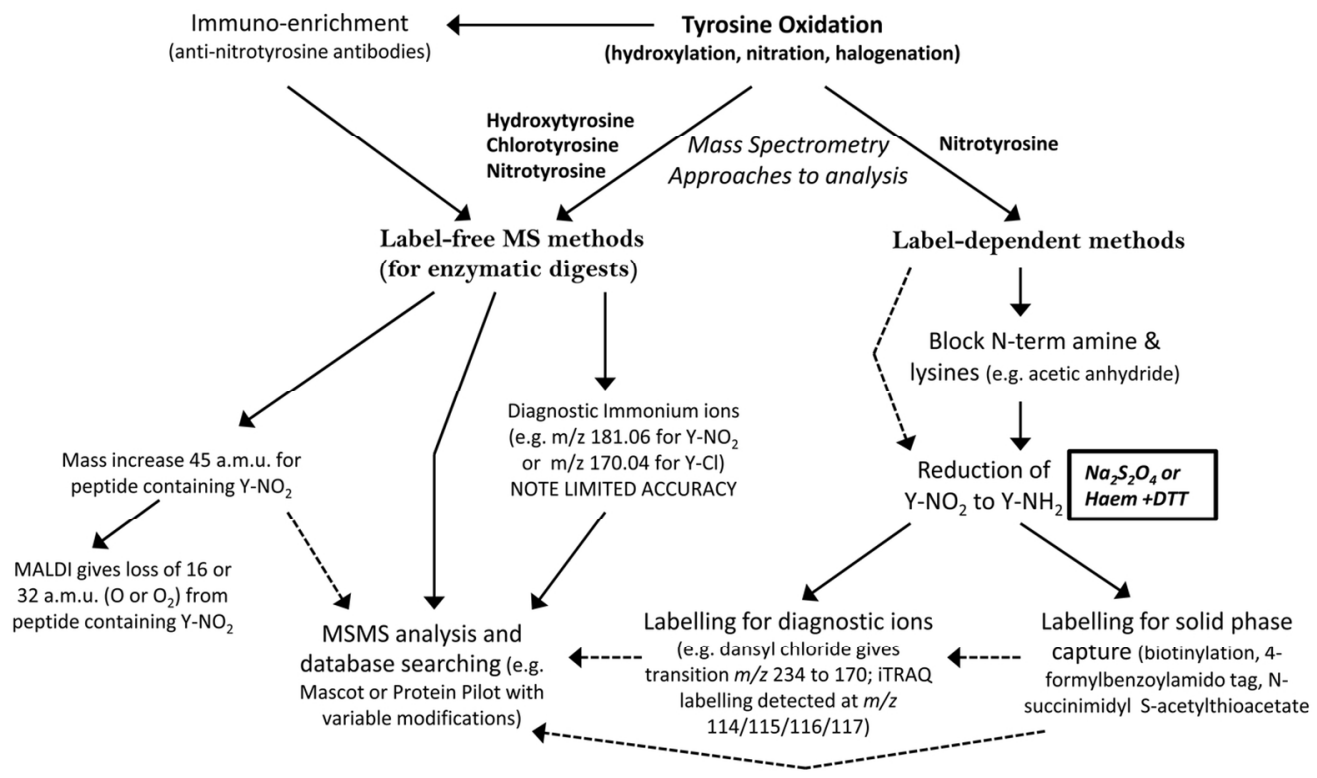

Figure 5. Mass spectrometry approaches to analysis of Tyr oxidation. Proteins containing oxidized Tyr can be separated by immuno-enrichment with specific antibodies, and subjected to label-dependent or independent methods for mass spectrometry analysis. Label-free methods use the change in mass-tocharge ratio $(\mathrm{m} / \mathrm{z})$ resulting from the modification to characterize the oxidation, while label-dependent methods are mostly used for 3-nitroTyr following reduction to 3-aminoTyr. They can then be used either for targeted enrichment, or label-dependent MS analysis, or both. In most cases, peptide fragmentation by MSMS is used to determine the sequence of the modified peptide with search engines such as Mascot by reference to a database of protein sequences. $125 \times 74 \mathrm{~mm}(300 \times 300 \mathrm{DPI})$ 


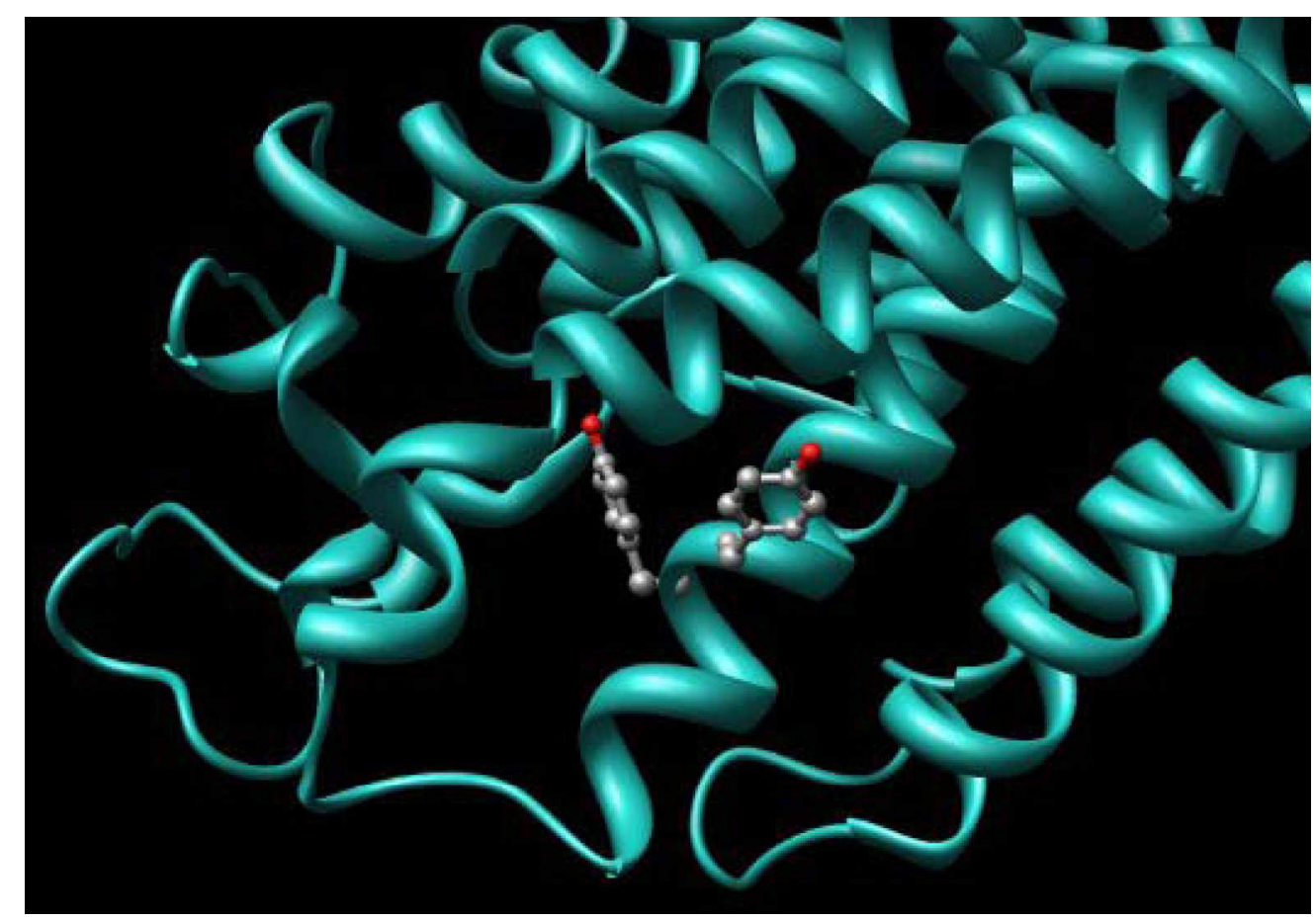

Figure 6. The two Tyr residues in SERCA that have been reported to be nitrated are Tyr294 and Tyr295. $91 \times 63 \mathrm{~mm}(600 \times 600 \mathrm{DPI})$ 


\section{NATIVE PROTEIN}

mild oxidation or nitration

Dopamine / dopamine quinone / 5,6-dihydroxyindol / nitrotyrosine

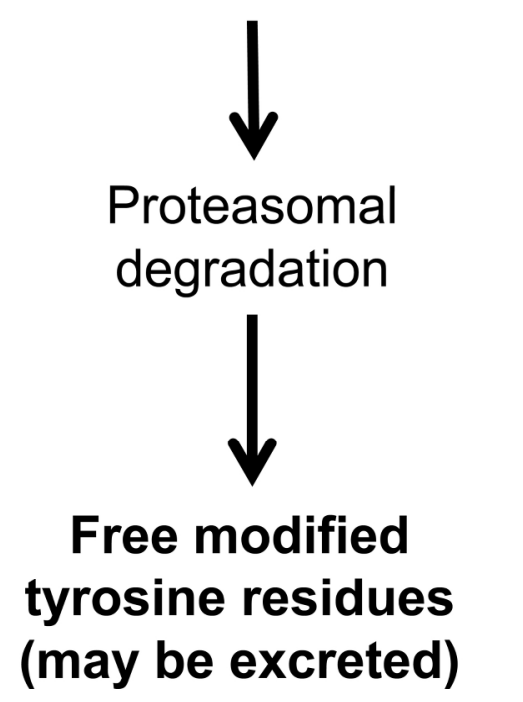

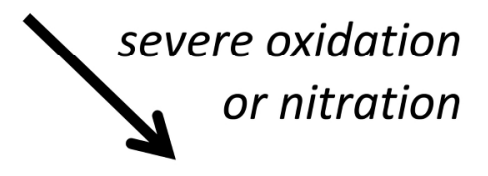

Dityrosine cross-links

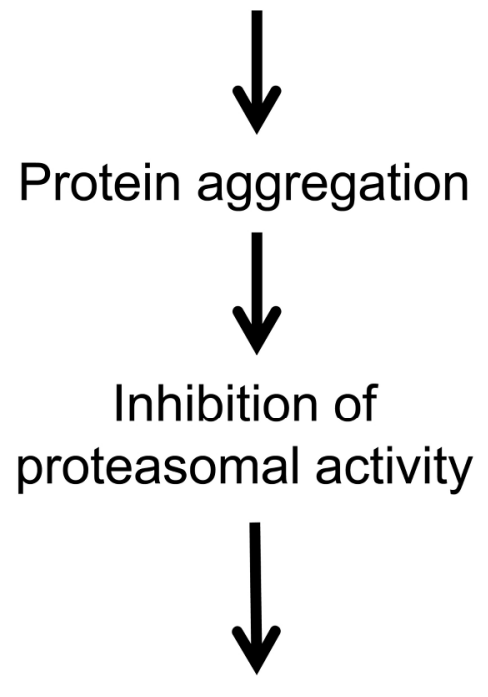

Cellular accumulation of protein aggregates

Figure 7. The possible fates of oxidized Tyr in proteins. $100 \times 95 \mathrm{~mm}(600 \times 600 \mathrm{DPI})$ 